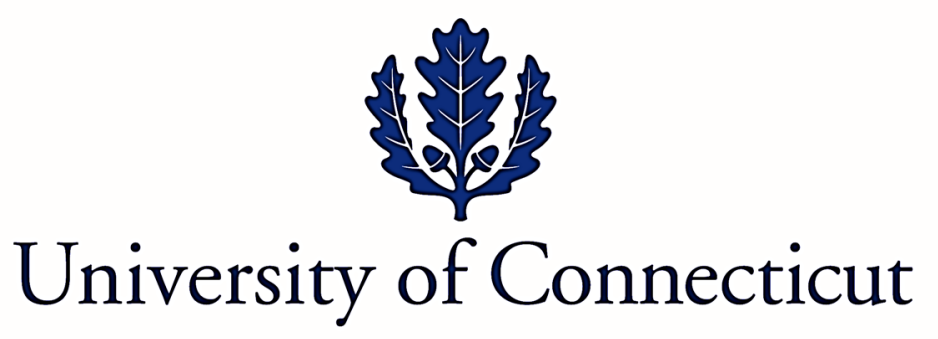

Department of Economics Working Paper Series

Nudges, College Enrollment, and College Persistence:

Evidence From a Statewide Experiment in Michigan

by

Joshua Hyman

University of Connecticut

Working Paper 2018-10

May 2018

365 Fairfield Way, Unit 1063

Storrs, CT 06269-1063

Phone: (860) 486-3022

Fax: (860) 486-4463

http://www.econ.uconn.edu/

This working paper is indexed in RePEc, http://repec.org 


\title{
Nudges, College Enrollment, and College Persistence: Evidence From a Statewide Experiment in Michigan
}

\author{
Joshua Hyman ${ }^{1}$ \\ University of Connecticut
}

May 31, 2018

\begin{abstract}
I conduct a statewide experiment in Michigan with nearly 50,000 high-achieving high school seniors. Treated students are mailed a letter encouraging them to consider college and providing them with the web address of a college information website. I find that very high-achieving, poor and minority students are the most likely to navigate to the website. Small changes to letter content have dramatic effects on take-up. For example, highlighting college affordability induces 18 percent more students to the website than highlighting college choice, and 37 percent more than highlighting how to apply to college. Poor students who are mailed the letter experience a 1.4 percentage point increase in the probability that they enroll in college, driven by increases at fouryear institutions. Unfortunately, these students tend not to persist through college, leading to an effect only half as large on the probability of enrolling and persisting to the second year of college, and a near zero impact on enrolling and persisting to the third year. These findings highlight the importance of supporting marginal college enrollees through college, and, for researchers, the necessity of examining persistence when evaluating college-going interventions.
\end{abstract}

\footnotetext{
${ }^{1}$ Department of Public Policy, 10 Prospect St., Fourth Floor, Hartford, CT 06103 (email: joshua.hyman@uconn.edu). Thank you to Venessa Keesler at the Michigan Department of Education for her partnership and support on this project. Thanks to John Bound, Eric Brunner, Thomas Downes, Susan Dynarski, Brian Jacob, Jeffrey Smith, Kevin Stange, Caroline Theoharides, and audience members at the University of Michigan, University of Connecticut, Federal Reserve Bank of Boston, Association for Education Finance and Policy, and Association for Public Policy Analysis and Management for helpful comments. I am grateful for research assistance from Diego Briones, Melissa Helburg, and Dana Sherry. Thanks to the Spencer Foundation for funding this project through grant 201400120, and to the Institute of Education Sciences, U.S. Department of Education for providing support through Grant R305E100008 to the University of Michigan. Thanks to my partners at the Michigan Department of Education (MDE) and Michigan's Center for Educational Performance and Information (CEPI). This research used data structured and maintained by the Michigan Consortium for Education Research (MCER). MCER data are modified for analysis purposes using rules governed by MCER and are not identical to those data collected and maintained by MDE and CEPI. Results, information, opinions, and any errors are my own and are not endorsed by or reflect the views or positions of MDE or CEPI.
} 


\section{Introduction}

Due to information constraints and administrative hurdles in the college and financial aid application process, many high-achieving, low-income students either do not apply to college or apply to colleges that are less-selective, under-resourced, and at which they will have a low probability of success (Hoxby \& Avery, 2013). Mentoring, in-person application assistance, and other "boots-on-the-ground" strategies to dismantle these hurdles have shown promising impacts, but are relatively expensive to implement (Bettinger, Long, Oreopoulos, \& Sanbonmatsu, 2012; Carrell \& Sacerdote, 2017; Oreopoulos \& Ford, 2016). Researchers evaluating a series of lighter-touch nudge and information interventions have found mixed results, with some studies finding null effects (Bettinger et al., 2012; Foote, Shulkind, \& Shapiro, 2015; Carrell \& Sacerdote, 2018; Bergman, Denning, \& Manoli, 2017; Phillips \& Reber, 2018), and others finding sizable impacts (Hoxby \& Turner, 2013; Castleman \& Page, 2015; Barr \& Turner, Forthcoming; Page \& Gelbach, 2017; Bird, Castleman, Goodman, \& Lamberton, 2017). While the studies finding positive impacts of light-touch interventions provide reason for cautious optimism, they have several limitations. First, with the exception of Bird et al. (2017), the interventions in these studies still tend to cost several dollars per student, which can be a barrier to large-scale implementation for budget-constrained states and school districts. Second, most focus on students who have already taken concrete steps toward applying to college, for example students who have taken a college entrance exam (Hoxby \& Turner, 2013) or signed up with the Common Application (Bird et al., 2017), thus missing the large fraction of highachieving, low-income students who never make it to these points in the college application process (Hyman, 2017a). Finally, a key concern with light-touch policies is that they may reduce informational and administrative hurdles to the college application process, but not provide 
students with any lasting improvements in their skills or knowledge, thus potentially inducing marginal students to attend but not persist through college. Studies that only estimate effects on attendance in the first year of college (e.g., Castleman \& Page, 2015; Page \& Gelbach, 2017; Oreopoulos \& Ford, 2016; Bird et al., 2017)² may overstate program benefits if marginal students induced into college drop out at a higher rate than the inframarginal student.

In this paper, I conduct a statewide experiment operating at-scale with nearly 50,000 high-achieving high school seniors in Michigan. Treated students were mailed a letter from the Michigan Department of Education encouraging them to consider applying to college and providing them with the web address of a website containing information about the college and financial aid application process. The intervention was inexpensive, costing only fifty cents per student. The experimental sample includes all Michigan eleventh grade students during 2013-14 who scored at least the statewide median on the ACT college entrance exam. Because the ACT was mandatory for Michigan students at this time, no active steps toward college application were necessary for students to enter the sample. The letter contained an individual-specific password allowing me to track who navigates to the website and their browsing behavior on the site. Students in the sample are currently college juniors, facilitating an examination of up to three years of college persistence in response to the intervention.

Approximately ten percent of treated students entered their password on the college information website, though this overall take-up rate masks substantial heterogeneity by student characteristic. Non-white students were three percentage points (twenty-four percent) more likely to take-up than white students, poor students were 1.2 percentage points (thirteen percent) more likely than non-poor students, and students scoring higher on the ACT were 6.3 percentage

\footnotetext{
${ }^{2}$ Bird et al. (2017) is a working paper, and the authors note that they plan to examine college persistence in a subsequent version of the paper.
} 
points (eighty-five percent) more likely than students with lower ACT scores. Poor, higherscoring students and non-white, higher-scoring students had the highest take-up rates suggesting that these groups of students are the most in need of information about the college and financial aid application process.

I find that small changes to letter content had dramatic effects on take-up. For example, including the phrase "Learn how to make college affordable" produced a take-up rate 1.8 percentage points (eighteen percent) higher than including the phrase "Learn which college is right for you," and 3.2 percentage points (thirty-seven percent) higher than the phrase "Learn how to apply to college.” Including all three phrases in the letter produced the lowest take-up rate, suggesting that providing too much information possibly "overloads” student decisionmaking. These differences represent a revealed-preference approach to determining which barriers students perceive to be most salient when applying to college. The findings suggest that most students perceive college affordability to be a more important barrier than understanding which college to apply to or how to apply. Consistent with this result, students were more likely to navigate to pages on the website, or click on links to external sites, related to college affordability.

Finally, I match the sample to data from the National Student Clearinghouse to examine effects on postsecondary outcomes. I find small, but statistically precise increases in college enrollment among poor students. These students were 1.4 percentage points, or nearly 2 percent, more likely to enroll in college, driven by increased enrollment at four-year colleges. Given the cost of only fifty cents per student, the intervention is substantially more cost-effective at boosting poor students' college enrollment than any other rigorously evaluated light-touch intervention of which I am aware, with the exception of the text messaging campaign evaluated 
in Bird et al. (2017), which also cost fifty cents per student and found similarly sized enrollment impacts.

While the present intervention's effects on enrollment appear quite promising given its low cost, the marginal students induced into college unfortunately tend not to persist through college. The intervention's impact on poor students' probability of enrolling in college and persisting to the second year is attenuated by about half, to 0.6 percentage points, and further shrinks to a near zero impact for enrolling and persisting to the third year of college.

I explore and rule out several possible mechanisms for this lack of persistence through college. Marginal students induced into college by the intervention were no more likely to enroll on a part-time basis than students in the control group. Nor did they tend to enroll in colleges that were a poor match based on student ability and college quality, or in colleges with low completion rates. Poor college enrollees from the treatment and control group are similar on observed baseline achievement as measured by high school GPA and ACT score. I conclude that the marginal high-achieving, poor students induced into college by the intervention likely drop out due to the same unobserved student and household factors that would have led them to not enroll in the absence of the intervention, likely related to a lack of information, support, and familiarity with college.

This paper makes important contributions to the literature evaluating policies to reduce the income gap in postsecondary attainment. The intervention I evaluate increased highachieving, poor students' likelihood of enrolling in postsecondary education, and did so at appropriately selective colleges. Unlike prior work finding positive effects of light-touch interventions, this intervention was extremely inexpensive, operated at-scale, and was not targeted only to students who had already taken concrete steps toward applying to college. The 
fact that the marginal students induced into college by the intervention tended to drop out highlights both the importance of programs that support marginal enrollees through college (e.g., Bettinger \& Baker, 2014; Castleman \& Page, 2016; Oreopoulos \& Petronijevic, 2018), and, for researchers, the necessity of examining persistence when studying college-going interventions.

The remainder of this paper is organized as follows. In the next section I first describe the intervention and data, and then report balance across the treatment and control groups. Section 3 presents results, focusing first on treatment group take-up and web-browsing behavior, and then turning to an evaluation of the effects of the intervention on postsecondary enrollment and persistence. Section 4 explores possible mechanisms, and Section 5 concludes.

\section{The Experiment}

This study uses a randomized control trial to evaluate the effects of a light-touch intervention implemented to high-achieving high school seniors in Michigan. The experimental sample contains the 49,156 eleventh grade public school students in Michigan during 2013-14 who scored at least a 20, the statewide median, on the ACT, which was mandatory for juniors in Michigan at this time. An ACT score of 20 was also the 25th percentile of Michigan students in the classes of 2008, 2009, and 2010 who earned a Bachelor’s degree within six years of high school graduation. ACT Inc. cites a score of 20 as likely qualifying a student for admission to a "traditional" four-year institution. ${ }^{3}$ In summary, the ACT score of 20 as the sample cutoff reflects my choice of a threshold that represents students with a good chance of admission to, and success at, a somewhat selective four-year institution.

\footnotetext{
${ }^{3}$ See ACT Inc (2002). A score of 18-21 likely qualifies a student for admission to non-selective institutions, 20-23 to traditional institutions, 22-27 to selective institutions, and 27-31 (or higher) to highly selective institutions.
} 
I randomly assigned half of the 49,156 students in the experimental sample to a treatment group and half to a control group. The 24,578 students in the control group received no additional information as part of this study. The 24,578 students assigned to the treatment group received the intervention described in detail in Section 2.1, directly below. I proceed to discuss the data in Section 2.2, and in Section 2.3, report summary statistics and compare balance across the treatment and control groups.

\subsection{The Intervention}

The basic intervention is a single page letter on Michigan Department of Education letterhead mailed to students during fall 2014, when the students were in twelfth grade. As shown in Figure I, the letter congratulates students on their ACT score and tells them that they are "receiving this message as part of a free service by the Michigan Department of Education to ensure that students who are qualified to succeed in college have the information necessary to successfully navigate the application process. ${ }^{* 4}$ I randomly assigned four treatment arms to test the relative importance of different information barriers to college application. The second paragraph of the letter begins: “The following link contains information and resources to help you..." For students assigned to the first treatment arm, this sentence is completed with the bolded phrase: "learn how to make college affordable." The second arm replaces that phrase with: "learn how to apply to college.” The third replaces it with: "learn which college is right for you.” Finally, the fourth version of the letter includes all three bolded phrases. ${ }^{5}$

The letters were mailed in letter-size, white business envelopes imprinted with the MDE logo and return address and displaying the student's name and home address through a clear,

\footnotetext{
${ }^{4}$ Note that all students in both the treatment and controls groups were already mailed an official score report from ACT during the previous spring.

${ }^{5}$ Figure I shows the college affordability version of the letter. Appendix Figures I, II, and III show the other letter versions.
} 
plastic window (see Figure IIa). In order to test whether mailing timing impacts take-up or college enrollment, I randomly assigned the month the letter was sent (i.e, October, November, or December). I also randomly varied the day of the week the letter would be sent (Monday or Thursday). The rationale for the former was that students may be more apt to respond to the letter at different points in the college application process. The rationale for the latter was that most letters mailed on Monday would arrive during the week, on Tuesday and Wednesday, while most letters mailed on Thursday would arrive during the weekend, on Friday and Saturday, when students may be more or less likely to open their mail. ${ }^{6}$

The letter contains a web address for a "college information website," micollegeinfo.org, and an individual-specific password. The web address directs students to a gateway website that I created for this study (Figure IIb) where students are prompted to enter their password, and then are redirected to a publicly available college information website.

I randomly assign half of the passwords to redirect students to https://KnowHow2GOMichigan.org (see Figure III). This college information website was created and maintained by the Michigan College Access Network (MCAN), a Michigan-based non-profit. ${ }^{7}$ I chose this website because through my collaboration with MCAN, I could track the web-browsing behavior of students who navigated to this site. The other half of the passwords redirected to https://bigfuture.collegeboard.org/, a college information website created by and maintained by the College Board (see Figure IV). Both sites were established with the intent to provide information about the college and financial aid application process, but The College Board website is well funded, more attractive, and arguably easier to navigate and better

\footnotetext{
${ }^{6} \mathrm{~A}$ logistical reason to vary the timing of the mailings was that MDE staff recommended against sending out nearly 25,000 letters from the MDE mail services department on a single date, due to processing constraints.

${ }^{7}$ The website is no longer active.
} 
designed. On the other hand, most students enroll in college in the state in which they attended high school, and many financial aid opportunities are state-specific. The MCAN website focuses on Michigan-specific college and financial aid information. The website randomization allows a test of whether any effects of the intervention on college enrollment outcomes differ by the website to which a student is directed. ${ }^{8}$

\subsection{Data}

This paper uses an individual-level dataset containing all eleventh grade students in Michigan public schools during the 2013-14 school year. The bulk of this data comes from the Michigan Department of Education (MDE) and Michigan Center for Educational Performance and Information (CEPI) student longitudinal database. These data contain time-invariant demographics such as student sex and race, as well as time-variant characteristics measured during eleventh grade, such as free and reduced-price lunch eligibility, which I use as a proxy for student poverty status. Students' ACT score is from the ACT exam that all students take during the spring of eleventh grade as part of Michigan's statewide standardized testing. ${ }^{9}$ The score is an official ACT score usable for college admissions. Students' grade point average (GPA) during eleventh grade, which I use as an additional baseline achievement measure, is also obtained from the MDE and CEPI database.

I use student names and home addresses to mail the letter, though these personally identifiable information were stripped from the dataset after the mailing was complete and replaced with unique student identifiers. Student addresses are reported to MDE from districts

\footnotetext{
${ }^{8}$ Note that I can only track web browsing behavior at https://KnowHow2GOMichigan.org. I contacted The College Board to ask permission to track web-browsing behavior at their website for this project, but the request was denied. ${ }^{9}$ See Hyman (2017a) and Garlick and Hyman (2018) for more details about the mandatory ACT exam in Michigan. I generally refer to the ACT composite score, though the data also include the ACT math, science, reading, and English subscores. The mandatory ACT in Michigan does not include the optional writing portion of the exam.
} 
three times per year, during the fall, winter, and end-of-year. I used the most recent address at the time of setting up the experiment, which was winter of eleventh grade.

For the purposes of this experiment I set up a web tracking system linked to the unique student identifiers in order to track which students navigate to the web address provided in the mailing and to examine their web-browsing on the KnowHow2GOMichigan.org college information website. In addition to viewing which students access the website and where they navigate, I observe the date and time they access the site, the amount of time they spend on each page, their IP address, their internet browser (e.g., Microsoft Explorer, Mozilla Firefox), and any link they click to exit the website.

Student-level postsecondary enrollment information is obtained by matching students to the National Student Clearinghouse (NSC). The NSC is a non-profit organization that houses postsecondary enrollment information on over ninety percent of undergraduate enrollment nationwide (Dynarski, Hemelt, \& Hyman, 2015). Finally, high school characteristics, such as urbanicity (i.e., urban, suburban, town, or rural status) and fraction of students eligible for free or reduced-price lunch, are obtained from the National Center for Education Statistics (NCES) Common Core of Data (CCD).

\section{$\underline{2.3 \text { Balance }}$}

Table 1 reports sample means by treatment status for the experiment. The first column reports student characteristics for the entire cohort of Michigan eleventh grade students with a valid ACT score during 2013-14 in order to show the differences between that sample and the experimental sample of students who scored at least a 20 (column 2). Columns 3 and 4 split the main sample into the control and treatment group, respectively. The remaining columns then split the treatment group by treatment arm and mailing timing. 
Comparing the entire cohort of eleventh grade students to those who scored at least a 20 on the ACT, the latter (experimental) sample has a slightly higher fraction female (51.6\% compared to $50.0 \%)$, higher fraction white (85.1\% compared to $74.3 \%)$ and Asian (4.5\% compared to $3.0 \%$ ), and lower fraction black (6.4\% compared to 16.8\%), Hispanic (3.0\% compared to $4.8 \%$ ), and poor (26.9\% compared to $43.4 \%)$. Students in the experimental sample are less likely to be from high schools in cities (9.7\% compared to $19.4 \%)$, and more likely to be from high schools in suburban areas (53.8\% compared to $47 \%$ ) and towns/rural areas (36.5\% compared to 33.6\%). High poverty high schools, defined as those above the median fraction eligible for free or reduced-price lunch, are less represented in the experimental sample than in the entire cohort (50.2\% compared to 63\%). Students in the experimental sample are, by design, positively selected on measures of student achievement. For example, the mean eleventh grade GPA is 3.20 compared to 2.68 among the entire cohort. Similarly, the mean ACT composite score is 24.1 compared to 19.8 among the entire cohort.

I now turn to columns 3 through 13 to explore balance between the treatment and control groups. There are no statistically significant differences between the overall treatment and control group or between any treatment arm and the control group for any of these characteristics. The statistical tests are conducted by regressing each characteristic on the treatment indicator, clustering the standard errors at the school-level. The F-test that all characteristics are jointly equal to zero has a p-value of 0.990. In summary, Table 1 provides strong evidence of balance, and thus that it is valid to estimate the causal impact of the intervention by comparing mean outcomes in the treatment group to those in the control group. 


\section{Results}

Given that the experiment was successful at randomizing students into treatment and control groups, I now turn to presenting the results of the experiment. I focus first in Section 3.1 on take-up of treated students entering their password on the gateway website, and describe their website browsing behavior in Section 3.2. I then examine impacts on postsecondary outcomes by comparing treated to control group students, focusing on postsecondary enrollment in Section 3.3, and persistence through college in Section 3.4.

\subsection{Take-Up}

Many of the treated students in this study may never open the envelope mailed to them by the Michigan Department of Education, or may open it and read the letter but never navigate to the recommended micollegeinfo.org web address. In this section, I explore what fraction of treated students “take-up” the intervention by navigating to micollegeinfo.org and entering their password on that website. ${ }^{10}$ In Table 2, column 1, I present the take-up rate for the overall treatment group in row 1 , and then in subsequent rows present heterogeneity in the take-up rate by student and school characteristic and student ACT score. In the final rows of Table 2, I present take-up rates by treatment arm and mailing timing. Column 2 shows the differences in take-up rate between these groups, and column 3 presents these differences in percent terms. Finally, column 4 shows the p-value from the test of equality of the take-up rate across the groups. $^{11}$

\footnotetext{
${ }^{10}$ Included in the denominator is the approximately two percent of letters that were returned with an invalid or outdated address.

${ }^{11}$ Statistical tests are conducted by separately estimating for each characteristic (e.g., sex, race, letter content) a regression of an indicator for take-up on the group indicator(s). These regressions are estimated for the treated students only, and standard errors are clustered at the school-level. P-values are from the test that the coefficient(s) on the group indicator(s) equal zero.
} 
Overall, 9.8 percent of students navigated to micollegeinfo.org and entered their password. I find no significant difference in take-up by student gender. Non-white students were 3 percentage points (24\%) more likely than white students to navigate to the website (statistically significant difference, with p-value of 0.000 ). Poor students were 1.2 percentage points (13\%) more likely than non-poor students to take-up (p-value of 0.011). Urban students were 1.8 and 1.7 percentage points (19\% and $18 \%)$ more likely to take-up than suburban and town/rural students, respectively (p-values of 0.009 and 0.016 ). ${ }^{12}$ Counter to the result by student poverty status, there was no difference in take-up by school poverty status. Students with higher ACT scores were much more likely to navigate to the site, with a take-up rate of 13.7 percent for students with scores of 26 or greater, 85 percent higher than the rate of 7.4 percent for students with scores of 20-22 (p-value of 0.000). ${ }^{13}$ Taken together, these results suggest that high-scoring, poor and minority students have the greatest rates of take-up. Figure V shows this to be true: high-scoring, poor students have a take-up rate of 16.6 percent (Figure Va) and high-scoring, non-white students have a take-up rate of 17.2 percent (Figure Vb).

In addition to understanding which types of students have unmet need regarding information about the college and financial aid application process, my experiment also aims to identify the topics about which students seek information. As described earlier, I explore this issue by splitting the treatment group into four arms that receive different letter versions, each with a different bolded phrase meant to highlight a specific information barrier to college application. If I find that some versions of the letter cause higher take-up, this would suggest that students find those barriers more salient.

\footnotetext{
${ }^{12}$ This pattern does not reflect differences by student poverty status, as the pattern by urbanicity is similar for poor and non-poor students (see Appendix Figure IVa).

${ }^{13}$ There is even greater variation in take-up within the group scoring 26 or higher, with take-up of 10-13 percent for students scoring 26-29, and take-up of 16-32 percent for students scoring 30-36 (see Appendix Figure IVb).
} 
I find substantial differences in take-up across the different versions of the letter (see Table 2). The letter that emphasized college affordability produced the highest take-up rate, 1.8 percentage points (18\%) higher than the letter that emphasized college choice (p-value from test of equality is 0.003 ), and 3.2 percentage points (37\%) higher than the letter that emphasized how to apply (p-value of 0.000). This pattern is the same for poor and for non-poor students (see Figure VI). The letter that included all three barriers produced the lowest take-up rate, suggesting that it is less effective to highlight too much information. Finally, I find that the timing of the mailing, either by month or by day of the week had no impact on take-up.

The dramatic heterogeneity by student and school characteristics arguably represents a revealed preference approach to determining which types of students (or their parents) desire information about the college and financial aid application process. I find that, consistent with past work (e.g., Hoxby \& Avery, 2013), the students with the most unmet need for this information are extremely high-achieving, poor and minority students. I also provide a revealed preference approach to determining students' perceived information barriers to college application, and find that college affordability is the barrier that resonates most for both poor and non-poor students alike.

\subsection{Browsing Behavior}

For the 1,167 students who entered their password on the gateway site and were directed to KnowHow2GOMichigan.org, I can examine their web-browsing behavior as another way to learn which college information barriers students perceive as most important. Panel A of Table 3 examines which types of webpages students navigated to within the site. ${ }^{14}$ I focus on three tabs on the main vertical menu-bar on the left-hand-side of the homepage (see Figure VI) that

\footnotetext{
${ }^{14}$ In general, the mean number of pages that students navigated to on the website, including the homepage, was three pages. Students spent an average of three minutes navigating the website.
} 
correspond loosely to the information barriers highlighted in the three letter versions. These tabs are labeled: "Paying for College,” "Student Steps,” and “Michigan College Search”. I find that 35.9 percent of students clicked on the tab “Paying for College,” while only 13.3 and 13.5 percent, respectively, navigated to the "Student Steps” and “Michigan College Search” pages. As in the prior analysis of take-up, these results demonstrate students’ revealed interest in learning about college affordability. Students who received the letter emphasizing college affordability were even more likely to navigate to the "Paying for College” page (51.5\%), while students who received the letter highlighting "learn which college is right for you” were more likely to navigate to the "Michigan College Search" page (21.2\%). ${ }^{15}$

Table 3, Panel B focuses on the students who left the KnowHow2GOMichigan.org website by clicking on a link to an external site. This panel shows the top five websites that students visited and the percentage of these students who visited that site. Four of these five sites are related to college affordability (e.g., "MDE Michigan Scholarship Website” and "See if You're Eligible for a Pell Grant”), and the top two sites are Michigan-specific (e.g., “Michigan College Access Portal”). These results again reinforce the revealed desire for information about college affordability, but also highlight that students tend to seek state-specific information about the college and financial aid application process.

\subsection{College Enrollment}

I now turn to estimating the effects of the intervention on postsecondary enrollment, choice, and persistence. The randomized nature of the experiment motivates a straightforward

\footnotetext{
${ }^{15}$ Note that these differences could partially reflect the letter type changing students' browsing behavior by prompting them to focus on the highlighted barrier, but could also reflect the letter type changing the composition of students navigating to the website to favor those students interested in the highlighted barrier.
} 
empirical strategy comparing the mean postsecondary outcome among the treatment group to that in the control group. Specifically, I estimate the following OLS regression:

$$
y_{i s}=\beta_{0}+\beta_{1} \text { Treat }_{i}+X_{i s}+\mu_{i s}
$$

where $y_{i s}$ is the postsecondary outcome for student, $i$, from high school, $s$, Treat is an indicator for whether the student was mailed a letter, $X$ includes the baseline student- and school-level covariates presented in Table 1 and $\mu$ is a random disturbance term. ${ }^{16}$

Results based on the estimation of equation (1) are presented in Table 4. The standard errors reported in Table 4 and all subsequent tables are clustered at the school-level to allow for within-school autocorrelation of the disturbance term. The first row of the table presents results based on specifications where the dependent variable is an indicator for whether a student enrolls in any college within two years after scheduled on-time high school graduation, where on-time graduation is based on the year the student was in eleventh grade. ${ }^{17}$

Among the entire sample, there is a near zero and statistically insignificant impact on the probability a student enrolls in any college (Table 4, column 1, row 1). Looking by student characteristics, the effect is larger, but still statistically insignificant for males. ${ }^{18}$ There is a 1.4 percentage point increase in college enrollment among poor students, which is statistically significant at the $95 \%$ level and represents a 1.8 percent increase off the control mean of 76.4

\footnotetext{
${ }^{16}$ See Appendix Table 1 for the main postsecondary enrollment, choice, and persistence results estimated excluding the vector of controls. The results are nearly identical, consistent with the strong balance presented in Table 1. Given that the outcome variables are dichotomous, I also show in Appendix Table 2 that the results are nearly identical when estimated using logit instead of OLS.

${ }^{17}$ This outcome can be thought of as a liberal measure of on-time college enrollment that in addition to capturing students who graduate high school on time and immediately enroll in college, also captures students either graduating high school on time and taking a gap year before enrolling, or students who take an extra year to graduate high school and then enroll the following fall.

${ }^{18}$ For each student subgroup examined in Table 4, I examine balance across treatment and control for the sixteen characteristics presented in Table 1. I find near perfect balance, with no statistically significant differences for most subgroups, and one statistically significant difference for three subgroups. For every subgroup I conduct an F-test that all characteristics are jointly equal to zero, and fail to reject the null in every case.
} 
percent. The coefficient for non-poor students is small and statistically insignificant, and I can reject the equality of the coefficients for the poor and non-poor samples, with a p-value of 0.019 . The point estimates for non-white students and for urban students are similar in magnitude to the point estimate for poor students, but they are statistically insignificant given the smaller sample sizes and thus lower statistical precision for these two groups.

It is worth noting that while the pattern of heterogeneity tends to show positive coefficients for the more disadvantaged groups, this pattern is not observed by ACT score or by school poverty. ${ }^{19}$ Also, the positive impact for poor students but not students at poor schools is consistent with the previous result that take-up is higher among poor students, but not at poor schools. This contrasts with prior work examining the impacts of education policy on students' college enrollment, which finds more dramatic effects for students at the poorest schools than for poor students (Dynarski, Hyman, \& Schanzenbach, 2013).

I turn now to examining effects by college type. The increase in college enrollment among poor students is driven by increases in attendance at four-year institutions. Poor students are 1.7 percentage points, or 3.2 percent, more likely to attend a four-year college during the two years after scheduled on-time high school graduation (significant at the 95\% level). Again, I can reject equality of the coefficients for the poor and non-poor samples, with a p-value of 0.030 . There is a small, negative, and statistically insignificant effect on enrolling only at a two-year college. ${ }^{20}$ There is a marginally significant increased probability that poor students attend a selective college, defined as being in the top two Barron's selectivity categories (e.g., the second

\footnotetext{
${ }^{19}$ I include males as a "disadvantaged” group in this statement, because their college enrollment rate is lower than for females both in my experimental sample, and more broadly in Michigan and across the U.S. (see Bailey \& Dynarski, 2011; Conger \& Long, 2013; Conger, 2015).

${ }^{20}$ For ease of interpretation, I define two-year enrollment as enrolling in a two-year school and not a four-year school, so that two- and four-year enrollment are mutually exclusive, and so the coefficients and control means in Table 4 sum to those shown in row 1 for any enrollment. There is a statistically insignificant 0.6 percentage point increase among poor students enrolling at a two-year school (including those who also enroll in a four-year).
} 
to highest Barron's category includes the University of Michigan). There is also a statistically significant increase in selective college enrollment among students at the poorest high schools. The near zero estimates for any college enrollment among low-scoring students and students at high-poverty schools masks some switching from two-year only to four-year enrollment, though these results are statistically imprecise. This pattern may also be at play in rural schools, where there is a marginally significant decrease in two-year enrollment, and similar sized (but insignificant) increase in four-year enrollment. ${ }^{21}$

In summary, while statistical imprecision makes it difficult to draw firm conclusions about many of the estimates, the statistically precise results for poor students indicate increases in enrollment, driven by shifts toward four-year and more selective colleges. ${ }^{22}$ I now examine whether these impacts exhibited heterogeneity by letter content, timing, or the website to which students were directed. I focus on poor students, given that they are the group for which I observed positive and statistically precise impacts of the intervention.

Table 5 presents these results, where for each column the sample is the control group plus the portion of the treatment group noted in the column header. While the results tend to be underpowered given the focus on poor students and particular subsets of the treatment group, several interesting patterns emerge. First, students who receive the college choice letter, and for whom we saw were subsequently more likely to navigate to the "College Search" portion of the

\footnotetext{
${ }^{21}$ I also examine in-state versus out-of-state attendance and find that the results are driven by increases at in-state institutions. I split four-year colleges into public versus private institutions, and find that the effects are somewhat more concentrated among privates than publics.

${ }^{22}$ All results are Intent-to-Treat (ITT) estimates, which I believe are more policy relevant than Treatment-on-theTreated (TOT) estimates given that no policy can force students to open an envelope, read the enclosed letter, and navigate to the suggested website. Furthermore, it is not clear that estimating TOT effects is appropriate in this context, given that reading the letter even without navigating to the gateway website could influence students' behavior. Nevertheless, when I estimate TOT effects that instrument for take-up with random assignment, I find an identical pattern of coefficients that are approximately ten times larger. For example, the TOT for poor students enrolling in any college is 13.5 percentage points, and for enrolling in a four-year college is 16.1 percentage points.
} 
Michigan website, may exhibit a switching effect, with a statistically imprecise decrease in twoyear enrollment and large, statistically significant increase in four-year enrollment. Second, the effects appear to be driven by the letters mailed in October and November. There is a smaller and statistically insignificant effect of letters mailed in December, which is well into collegeapplication season, and perhaps too late to impact student decisions. The effects by website are nearly identical revealing either that the website design is unimportant, or that any possible gains due to the better design of the College Board site may be offset by the more comprehensive state-specific information in the Michigan site.

\section{$\underline{3.4 \text { College Persistence }}$}

While college entry has been rising in recent decades, college completion has remained

flat (Bound, Lovenheim, \& Turner, 2010). I have documented that the present intervention had important impacts on poor students' college enrollment, however, a key concern with policies that boost college-going is that they may induce marginal students to attend but not persist through college. This concern exists for any policy that increases college enrollment, such as Head Start (Deming, 2009), primary school class size reduction (Dynarski, Hyman, \& Schanzenbach, 2013), or increases in school funding (Jackson, Johnson, \& Persico, 2016; Hyman 2017b). However, the concern is even greater for light-touch policies, such as the one implemented in this study, because such interventions reduce informational and/or administrative hurdles to the college application process, but may not provide students with any lasting improvements in their skills or knowledge that can help them persist through college. If students 
induced into college do not persist to graduation, then the effects on enrollment rates of such policies would overstate the programs' benefits. ${ }^{23}$

Given these concerns, I next examine the effects of the intervention on students' likelihood of enrolling in and persisting through college. The most recent college enrollment data available for this study is for fall 2017, which is the third fall after scheduled on-time high school graduation. Thus, for students who enroll during the first two years after scheduled on-time high school graduation (the measure used thus far), we can examine whether these students persist to the second year of college. ${ }^{24}$ In Table 6, row 1, I find that the effect among poor students on the probability of enrolling and persisting to the second year of college equals 0.6 percentage points, which is attenuated by about half relative to the 1.4 percentage point enrollment impact, and is no longer statistically significant. Assuming that the intervention does not negatively impact the persistence rate of students who would have enrolled in the absence of the intervention, this suggests that approximately half of those students induced into college do not persist to their second year. The pattern is similar and if anything somewhat more severe for enrolling in and persisting at four-year institutions.

I next examine enrollment and persistence to year three. To do so, I must redefine my measure of college enrollment to only capture enrollment within the year directly after scheduled on-time high school graduation, rather than enrollment within two years. Doing so allows me to examine whether students who enroll immediately in 2015-16, persist through 2016-17 and into their third year of college in fall 2017. I first present the results on immediate enrollment. The intervention increases immediate enrollment among poor students by 1.3 percentage points,

\footnotetext{
${ }^{23}$ It is worth noting that at least some amount of college dropout is rational and welfare improving from an economic standpoint given the option value of college attendance: enrolling in college provides students with the option, but not the obligation, to continue after learning whether college is right for them (e.g., Stange, 2012). ${ }^{24}$ Note that throughout this section I define persistence as persisting either at the same or a different institution.
} 
nearly identical to before, though the effect on four-year enrollment is only 1.0 percentage points, which is smaller than before and statistically insignificant. ${ }^{25}$ The point estimate among poor students for enrolling in any college and persisting to year three is near zero (0.1 percentage points), suggesting that most students induced into college drop out by year three.

\section{$\underline{\text { 4. Mechanisms }}$}

The stark and fairly sudden dropout of the marginal students induced into college by the intervention raises the question of what leads these students to drop out. In Table 7, I explore a few possible mechanisms for why these students may not persist through college. First, recall that effects on enrollment were driven by increases in four-year enrollment, with possible increases at selective colleges and decreases at two-year schools. One mechanism could be that students are being induced into "reach" institutions where they are among the lowest achievers and possibly less qualified to succeed at such colleges, similar to the concern raised in response to affirmative action postsecondary policies (see Arcidiacono \& Lovenheim, 2016).

I find little support for this possible mechanism. I categorize students as enrolling in a safety college, or “undermatching” (e.g., Bowen, Chingos, \& McPherson, 2011; Hoxby \& Avery, 2013; Dillon \& Smith, 2017), enrolling in a match college, or enrolling in a reach college (i.e., "overmatching”). ${ }^{26}$ I find a negative, statistically insignificant effect on only enrolling in a

\footnotetext{
${ }^{25}$ This immediate enrollment result no longer captures students enrolling in a two-year school for their first year and then transferring to a four-year school for their second year. Thus, the smaller immediate four-year enrollment effect, but same size immediate any enrollment effect, is consistent with the earlier finding that the intervention caused some students to switch away from enrolling only at a two-year institution.

${ }^{26}$ I define match, reach, and safety colleges broadly following Dillon and Smith (2017), such that a match college is one where the student's ACT score is within the interquartile range of entering freshman at that institution during 2015-16, which I acquire from the federal Department of Education's Integrated Postsecondary Education Data System (IPEDS). A reach school is one where the student's score is at or below the 25th percentile. A safety school is one where the student's score is at or above the 75th percentile score, and also includes non-selective four-year and two-year colleges that do not require the ACT or SAT. For each four-year college in IPEDS, I use the
} 
safety college. The positive enrollment effect for poor students is driven by increases at match colleges, with an increase of 0.18 percentage points that is statistically significant at the $95 \%$ level. There is also a small, statistically insignificant increase ( 0.5 percentage points) in enrolling at a reach college. While there are arguments for why students could be less likely to persist at either safety or reach colleges, there is little reason to expect lower persistence at match colleges. Thus, the student-college mismatch hypothesis does not appear to explain the lack of persistence through college among students induced to enroll by this intervention.

It is possible that students are induced into match colleges, but that these colleges tend to have relatively low persistence and graduation rates. I examine this possible mechanism by splitting colleges into those with relatively low persistence rates and those with relatively high persistence rates. ${ }^{27}$ The effect among poor students for enrolling only at a low-persistence college is near zero and statistically insignificant, while the point estimate for enrolling at a highpersistence college is 1.4 percentage points (marginally significant). To the extent that two-year colleges have lower persistence rates than four-year colleges, and especially selective four-year colleges, this result is consistent with the earlier enrollment results by college type. Thus, enrollment at low-persistence colleges does not appear to explain the lack of persistence for the marginal poor students induced into college by this intervention.

Finally, I examine enrollment intensity as a possible mechanism. Students who enroll primarily part-time are less likely to persist through college and earn a college degree (Shapiro et al., 2017). If the poor students induced by this intervention to enroll in college do so primarily

interquartile range for the college entrance exam (ACT or SAT) that is reported by more entering freshmen. In cases where this is the SAT, I convert scores to the ACT metric using publicly available concordance tables.

${ }^{27}$ I take all colleges attended in my experimental sample and divide them into low-persistence colleges, where the mean persistence rate is below the median rate in my data, and high-persistence colleges, where the mean persistence rate is above the median. I use persistence to the second year of college, but the pattern of results is identical if I use persistence to year three. 
part-time, then this could explain their high dropout rate. While the results are statistically imprecise, I do not find any convincing evidence that this mechanism is at play. The point estimate for enrolling only on a part-time basis is 0.5 percentage points, and is 0.9 for ever enrolling full-time (neither is statistically significant). While the results are imprecise, there is certainly no clear evidence that most students induced into college are doing so primarily on a part-time basis.

In summary, none of the mechanisms that I can test empirically with available data provide any support for the results on college persistence. After ruling out these mechanisms, it seems the most likely explanation is that these poor students are, by definition, marginal in that they would not have enrolled in the absence of this extremely light-touch intervention, but did enroll after being treated with the intervention. These marginal students may be less academically prepared or able to succeed in college than the inframarginal student. As an attempt to examine whether they are less academically prepared, I compare observable baseline achievement of these students, and find that treatment and control students who enrolled in college (or at a four-year college) have nearly identical and statistically indistinguishable ACT scores and eleventh grade GPAs. Thus, changes in student composition, at least along observed achievement measures, do not provide an explanation.

I conclude that the same unobserved characteristics of these high-achieving, poor students that may have been partially responsible for them not enrolling in college in the absence of the intervention, for example, not having family or friends who attended and are subsequently familiar with college, having challenging family circumstances that require their time and attention, having to financially support their immediate or extended families, etc., likely also lead to these students dropping out of college. While the intervention provided the nudge or increased 
information necessary to induce these students into college, it may not have solved any of these other possible issues that would lead students to drop out.

\section{Conclusion}

I conduct a statewide experiment in Michigan with nearly 50,000 high-achieving high school seniors. Treated students are mailed a letter from the Michigan Department of Education encouraging them to consider college and providing them with a web address for a college information website. I find that very high-achieving, poor and minority students are the most likely to navigate to the website. Small changes to letter content have dramatic effects on takeup. For example, highlighting college affordability induces 18 percent more students to the website than highlighting college choice, and 37 percent more than highlighting how to apply to college. Poor students who are mailed the letter experience a 1.4 percentage point increase in the probability that they will enroll in college, driven by increases at four-year institutions. However, these students tend to drop out leading to a smaller effect on the probability of enrolling and persisting to the second year of college, and a near zero impact on enrolling and persisting to year three.

In many ways, the finding that these students dropped out of college limits the future usefulness of this intervention, at least without partnering it with policy to boost persistence. Nevertheless, the fact that mailing the letter had a positive impact on poor students' enrollment represents an important contribution to the literature examining college-going interventions. Unlike prior work finding positive effects of light-touch interventions, this intervention was extremely inexpensive, operated at-scale, and was not targeted only to students who had already taken concrete steps toward applying to college. At a cost of approximately fifty cents per 
student to print and mail the letters, ${ }^{28}$ this intervention is among the cheapest rigorously evaluated college-going interventions of which I am aware.

To examine the relative cost-effectiveness of this intervention at increasing college enrollment, I compare the policy to other light-touch interventions that increase college-going among low-income populations. I create an index of cost-effectiveness by dividing a policy's cost by the proportion of students it induces into college. For example, assuming a $\$ 0.50$ per student cost and focusing on the 1.4 percentage point enrollment increase among poor students, the amount spent by this intervention to induce a single poor child into college is $\$ 36$ (= $\$ 0.50$ / $0.014) .{ }^{29}$

Carrell and Sacerdote (2017) evaluate a mentoring intervention that, if targeted toward women as there was no impact for men, costs $\$ 1,200$ per additional enrollee ( $\$ 300 / 0.25$ ). The H\&R Block FAFSA assistance program (Bettinger et al., 2012) costs $\$ 1,100$ per student induced into college (= \$88 / 0.08). The virtual college assistant evaluated by Page and Gelbach (2017) costs \$333 per college enrollee (\$11 / 0.033). Hoxby and Turner (2013), though focusing on college match and not the extensive margin of enrollment, spent \$6 per student and improved the college match rate by 5 percentage points, for a cost of $\$ 120$ (\$6 / 0.05) per student induced into a better-fit college. Castleman and Page (2015) evaluate a text messaging campaign that costs $\$ 100$ per student induced into college (\$7 / 0.07). To my knowledge, the most cost-effective of any rigorously evaluated light-touch intervention is the text messaging campaign evaluated by

\footnotetext{
${ }^{28}$ The cost of the experiment was slightly higher than fifty cents per student due to the staffing costs for setting up the gateway website and tracking students entering that site and their browsing behavior at the publicly available Michigan website. However, a state wishing to implement this intervention could bypass this gateway site, directing students outright to the publicly available website.

${ }^{29}$ One way to think of this calculation is as follows: if 1,000 poor students are treated with the policy at a cost of $\$ 0.50$ per student, 14 will be induced to attend college $(=1,000 \times 0.014)$ at a total cost of $\$ 500(=\$ 0.50 \times 1,000)$. Thus, the cost per student induced into college is $\$ 36$ (= \$500 / 14).
} 
Bird et al. (2017), with a cost per low-income student induced into college of $\$ 45$ (\$0.50 / 0.011).

At \$36 per low-income student induced into college, the present intervention dominates all previously evaluated light-touch college-going interventions in terms of the cost to induce an additional low-income student into college. This finding represents an important contribution to the literature that can help guide future policy surrounding the design and implementation of college-going nudges. Furthermore, the fact that the marginal students induced into college by the intervention tended to drop out highlights both the importance of programs that support marginal enrollees through college (e.g., Bettinger \& Baker, 2014; Castleman \& Page, 2016; Oreopoulos \& Petronijevic, 2018), and, for researchers, the necessity of examining persistence when studying college-going interventions.

\section{$\underline{\text { References }}$}

ACT Inc. (2002). Interpreting ACT Assessment Scores. Research Publication.

Arcidiacono, P., \& Lovenheim, M. (2016). Affirmative action and the quality-fit trade-off. Journal of Economic Literature, 54, 3-51.

Bailey, M. J., \& Dynarski, S. M. (2011). Gains and gaps: A historical perspective on inequality in college entry and completion. In Whither Opportunity: Rising Inequality, Schools, and Children’s Life Chances, edited by Greg Duncan and Richard Murnane, 117-133. New York, NY: The Russel Sage Foundation.

Barr, A., \& Turner, S. (Forthcoming). A letter of encouragement: Does information increase post-secondary enrollment of UI recipients? American Economic Journal: Economic Policy.

Bettinger, E. P., \& Baker, R. B. (2014). The effects of student coaching: An evaluation of a randomized experiment in student advising. Educational Evaluation and Policy Analysis, 36, 3-19. 
Bettinger, E. P., Long, B., Oreopoulos, P., \& Sanbonmatsu, L. (2012). The role of application assistance in college decisions: Results from the H\&R Block FAFSA experiment. The Quarterly Journal of Economics, 127, 1205-1242.

Bergman, P., Denning, J. T., \& Manoli, D., (2017) Broken tax breaks? Evidence from a tax credit information experiment with 1,000,000 students. IZA discussion paper no. 10997.

Bird, K.A., Castleman, B. L., Goodman, J., \& Lamberton, C. (2017). Nudging at a national scale: Experimental Evidence from a FAFSA completion campaign. EdPolicyWorks working paper no. 55.

Bound, J., Lovenheim, M. F., \& Turner, S. (2010). Why have college completion rates declined? An Analysis of changing student preparation and collegiate resources. American Economic Journal: Applied Economics, 2, 129-157.

Bowen, W. G., Chingos, M. M., \& McPherson, M. S. (2011) Crossing the finish line: completing college at America’s public universities. Princeton, NJ: Princeton University Press.

Carrell, S., \& Sacerdote, B. (2017) Why Do College-Going Interventions Work? American Economic Journal: Applied Economics, 9, 124-151.

Castleman, B. L., \& Page, L. C. (2015). Summer nudging: Can personalized text messages and peer mentor outreach increase college going among low-income high school graduates? Journal of Economic Behavior and Organization, 115, 144-160.

Castleman, B. L., \& Page, L. C. (2016). Freshman year financial aid nudges: An experiment to increase FAFSA renewal and college persistence. Journal of Human Resources, 51, 389415.

Conger, D. (2015). High school grades, admission policies, and the gender gap in college enrollment. Economics of Education Review, 46, 144-147.

Conger, D., \& Long, M. C. (2013). Gender gaps in college enrollment: The role of gender sorting across public high schools. Educational Researcher, 42, 371-380.

Deming, D. (2009). Early childhood intervention and life-cycle skill development: Evidence from Head Start. American Economic Journal: Applied Economics, 1, 111-134.

Dillon, E., \& Smith, J. (2017). Determinants of the match between student ability and college quality. Journal of Labor Economics, 35, 45-66. 
Dynarski, S., Hemelt, S., \& Hyman, J. (2015). The missing manual: Using national student clearinghouse data to track postsecondary outcomes. Educational Evaluation and Policy Analysis, 37, 53S-79S.

Dynarski, S., Hyman, J., \& Schanzenbach, D.W. (2013). Experimental evidence on the effect of childhood investments on postsecondary attainment and degree completion. Journal of Policy Analysis and Management, 32, 692-717.

Foote, A., Shulkind, L., \& Shapiro, T. M. (2015). Missed signals: The effect of ACT collegereadiness measures on post-secondary decisions. Economics of Education Review, 46, 39-51.

Garlick, R., \& Hyman, J. (2018). Quasi-experimental evaluation of alternative sample selection corrections. Working paper.

Hoxby, C., \& Avery, C. (2013). The missing “one-offs”: The hidden supply of high-achieving, low income students. Brookings Papers on Economic Activity, 1-65.

Hoxby, C. \& Turner, S. (2013). Expanding college opportunities for high-achieving, low income students. Stanford Institute for Economic Policy Research.

Hyman, J. (2017a) ACT for all: The effect of mandatory college entrance exams on postsecondary attainment and choice. Education Finance and Policy, 12, 281-311.

Hyman, J. (2017b) Does money matter in the long run? Effects of schools spending on educational attainment. American Economic Journal: Economic Policy, 9, 256-280.

Jackson, C., Johnson, R., \& Persico, C. (2016). The effects of school spending on educational and economic outcomes: Evidence from school finance reforms. The Quarterly Journal of Economics, 131, 157-218.

Oreopoulos, P., \& Ford, R. (2016). Keeping college options open: A field experiment to help all high school seniors through the college application process. NBER working paper 22320.

Oreopoulos, P., \& Petronijevic, U. (2018). Student coaching: How far can technology go? Journal of Human Resources, 53, 299-329.

Page, L. C., \& Gehlbach, H. (2017). How an artificially intelligent virtual assistant helps students navigate the road to college. AERA Open, 3, 1-12.

Phillips, M., \& Reber, S. (2018). When "low touch" is not enough: Evidence from a random assignment college access field experiment. CCPR working paper 2018-008. 
Shapiro, D., Dundar, A., Huie, F., Wakhungu, P.K., Yuan, X., Nathan, A. \& Bhimdiwali, A. (2017). Completing College: A National View of Student Completion Rates - Fall 2011 Cohort (Signature Report No. 14). Herndon, VA: National Student Clearinghouse Research Center.

Stange, K. M. (2012). An empirical investigation of the option value of college enrollment. American Economic Journal: Applied Economics, 4, 49-84. 
RCT Sample: ACT Score >= Median

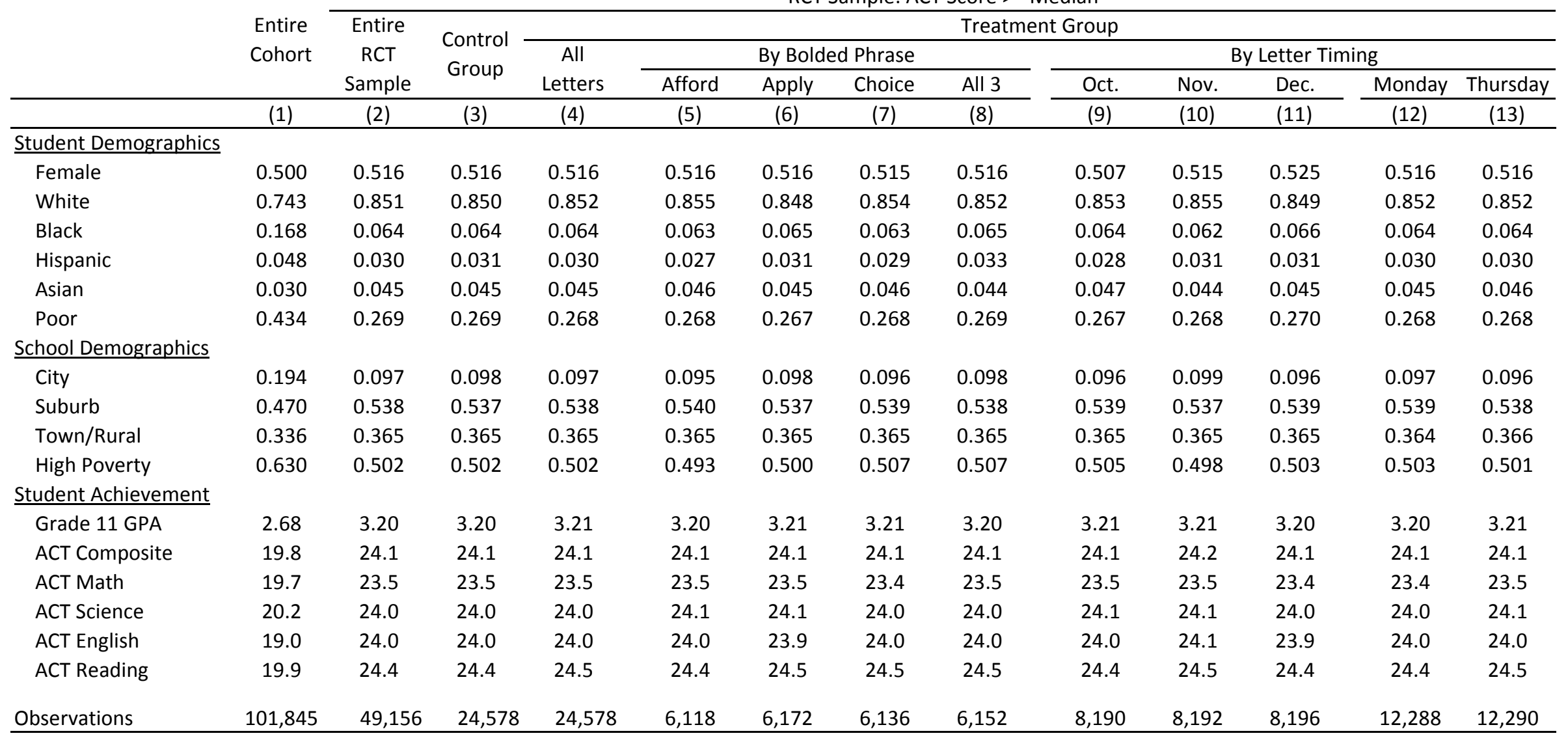

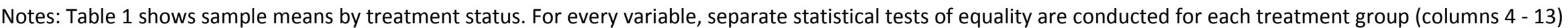

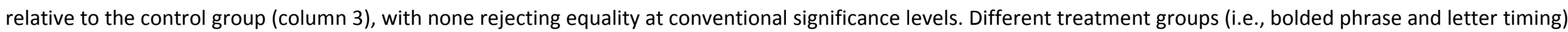
explained in text. High (low) school poverty is above (below) the median fraction eligible for free or reduced-price lunch in the RCT sample.

$* * *=$ significant at $1 \%$ level, $* *=5 \%$ level, $*=10 \%$ level 
Table 2. Treatment Group Take-Up Rates and Heterogeneity

\begin{tabular}{|c|c|c|c|c|}
\hline & \multirow{2}{*}{$\begin{array}{c}\text { Take-Up } \\
\text { Rate }\end{array}$} & \multicolumn{3}{|c|}{ Difference } \\
\hline & & Pctg. Pts. & Percent & P-Value \\
\hline & $(1)$ & $(2)$ & (3) & (4) \\
\hline All Treated Students & 0.098 & & & \\
\hline \multicolumn{5}{|c|}{ By Student Demographic } \\
\hline Male & 0.099 & & & \\
\hline Female & 0.097 & 0.003 & 2.6 & 0.527 \\
\hline Non-White & 0.124 & & & \\
\hline White & 0.094 & 0.030 & 24.2 & 0.000 \\
\hline Poor & 0.107 & & & \\
\hline Non-Poor & 0.095 & 0.012 & 12.5 & 0.011 \\
\hline \multicolumn{5}{|c|}{ By School Demographic } \\
\hline City & 0.114 & & & \\
\hline Suburb & 0.096 & 0.018 & 19.2 & 0.009 \\
\hline Town/Rural & 0.097 & 0.017 & 18.0 & 0.016 \\
\hline High Poverty & 0.099 & & & \\
\hline Low Poverty & 0.097 & 0.002 & 2.1 & 0.662 \\
\hline \multicolumn{5}{|l|}{ By Student ACT Score } \\
\hline $20-22$ & 0.074 & 0.063 & 85.1 & 0.000 \\
\hline $23-25$ & 0.091 & 0.046 & 50.8 & 0.000 \\
\hline $26+$ & 0.137 & & & \\
\hline \multicolumn{5}{|l|}{ By Letter Content } \\
\hline Affordability & 0.120 & & & \\
\hline How to Apply & 0.087 & 0.032 & 37.1 & 0.000 \\
\hline College Choice & 0.102 & 0.018 & 18.0 & 0.003 \\
\hline All Three & 0.084 & 0.036 & 43.6 & 0.000 \\
\hline \multicolumn{5}{|l|}{ By Letter Timing } \\
\hline October & 0.100 & & & \\
\hline November & 0.099 & 0.001 & 1.3 & 0.804 \\
\hline December & 0.095 & 0.005 & 5.3 & 0.287 \\
\hline Monday & 0.097 & 0.002 & 2.2 & 0.574 \\
\hline Thursday & 0.099 & & & \\
\hline
\end{tabular}

Notes: The sample is the 24,578 students in the treatment group. Column 1 shows mean take-up rates for the entire treatment group (row 1 ) and by student and letter characteristics (subsequent rows). Column 2 shows the difference in the take-up rate between the indicated group and the omitted group in percentage points. Column 3 represents this difference as a percent relative to the indicated group's level. Column 4 shows the $p$-value of the test of equality between the two groups. 


\section{Table 3. College Information Website Browsing Behavior}

Panel A. What Types of Webpages Did Students Navigate To?

\begin{tabular}{lccccc} 
& & \multicolumn{4}{c}{ By Letter Content } \\
\cline { 2 - 6 } Percent Navigating to: & All Letters & Affordability & Apply & Choice & Includes All 3 \\
\cline { 2 - 6 } & $(1)$ & $(2)$ & $(3)$ & $(4)$ & $(5)$ \\
\hline Paying for College & 35.9 & 51.5 & 26.5 & 24.4 & 37.1 \\
Student Steps & 13.3 & 13.9 & 11.1 & 15.6 & 11.7 \\
College Search & 13.5 & 8.6 & 11.1 & 21.2 & 13.3 \\
\hline
\end{tabular}

\section{Panel B. What External Links Did Students Navigate To?}

\begin{tabular}{lcc} 
Top Five Websites Students Leave To: & Percent & Cum. Percent \\
\hline Michigan College Access Portal & 25.3 & 25.3 \\
MDE Michigan Scholarship Website & 15.2 & 40.5 \\
Search for Scholarships & 12.0 & 52.5 \\
See if You're Eligible for a Pell Grant & 7.1 & 59.6 \\
See if You're Eligible for an Academic & 7.1 & \\
Competitiveness Grant & & 66.7 \\
Other & 33.3 & 100.0
\end{tabular}

Notes: The sample is the 1,167 students who entered their password on the gateway website and were directed to the KnowHow2GOMichigan.org college information website. Panel A shows the percent of students who navigated to different pages on that website by the letter version they were sent. Panel B shows the top five external website links to which students navigated. 
Table 4. Effects on College Enrollment, by College Type and Student Subgroup

\begin{tabular}{|c|c|c|c|c|c|c|c|c|c|c|c|c|c|c|}
\hline \multirow[b]{3}{*}{ Dependent Variable } & \multirow{3}{*}{$\begin{array}{c}\begin{array}{c}\text { All } \\
\text { Students }\end{array} \\
(1)\end{array}$} & \multicolumn{2}{|c|}{ Sex } & \multicolumn{2}{|c|}{ Poverty Status } & \multicolumn{2}{|c|}{ Race } & \multicolumn{2}{|c|}{ ACT Score } & \multicolumn{3}{|c|}{ School Urbanicity } & \multicolumn{2}{|c|}{ School Poverty } \\
\hline & & Male & Female & Poor & Non-Poor & Non-White & White & Low ACT & High ACT & City & Suburb & Town/Rural & High & Low \\
\hline & & (2) & (3) & (4) & (5) & (6) & (7) & (8) & (9) & (10) & $(11)$ & $(12)$ & (13) & (14) \\
\hline \multirow{3}{*}{ Enroll in College } & 0.001 & 0.007 & -0.005 & $0.014^{* *}$ & -0.005 & 0.013 & -0.002 & 0.000 & 0.001 & 0.013 & -0.001 & -0.001 & 0.001 & -0.000 \\
\hline & $(0.003)$ & $(0.005)$ & $(0.004)$ & $(0.007)$ & $(0.003)$ & (0.009) & $(0.003)$ & $(0.005)$ & $(0.004)$ & $(0.011)$ & $(0.004)$ & $(0.005)$ & $(0.005)$ & $(0.004)$ \\
\hline & 0.843 & 0.811 & 0.873 & 0.764 & 0.872 & 0.838 & 0.844 & 0.798 & 0.891 & 0.831 & 0.855 & 0.828 & 0.816 & 0.871 \\
\hline \multicolumn{15}{|l|}{ By College Level } \\
\hline \multirow[t]{3}{*}{ Four-Year } & 0.003 & 0.006 & -0.000 & $0.017 * *$ & -0.002 & 0.010 & 0.002 & 0.006 & -0.000 & -0.002 & -0.000 & 0.008 & 0.006 & -0.000 \\
\hline & $(0.004)$ & $(0.006)$ & $(0.005)$ & $(0.008)$ & $(0.005)$ & $(0.010)$ & $(0.004)$ & $(0.006)$ & $(0.005)$ & $(0.012)$ & $(0.005)$ & $(0.007)$ & $(0.006)$ & $(0.005)$ \\
\hline & 0.675 & 0.629 & 0.719 & 0.536 & 0.726 & 0.694 & 0.672 & 0.567 & 0.791 & 0.655 & 0.706 & 0.636 & 0.613 & 0.738 \\
\hline \multirow[t]{3}{*}{ Two-Year (only) } & -0.002 & 0.001 & -0.005 & -0.003 & -0.002 & 0.003 & -0.003 & -0.006 & 0.001 & 0.015 & -0.000 & $-0.009 *$ & -0.005 & -0.000 \\
\hline & $(0.003)$ & $(0.005)$ & $(0.004)$ & $(0.007)$ & $(0.004)$ & $(0.007)$ & $(0.004)$ & $(0.005)$ & $(0.004)$ & $(0.010)$ & $(0.004)$ & $(0.006)$ & $(0.005)$ & $(0.004)$ \\
\hline & 0.168 & 0.182 & 0.154 & 0.228 & 0.146 & 0.145 & 0.172 & 0.231 & 0.100 & 0.175 & 0.150 & 0.192 & 0.203 & 0.133 \\
\hline Enroll in Selective & 0.003 & 0.004 & 0.002 & $0.005^{*}$ & 0.002 & 0.008 & 0.002 & 0.002 & 0.004 & 0.008 & 0.001 & 0.004 & $0.006^{* *}$ & -0.001 \\
\hline \multirow[t]{2}{*}{ Four-Year } & $(0.002)$ & $(0.003)$ & $(0.003)$ & $(0.003)$ & $(0.003)$ & $(0.006)$ & $(0.002)$ & $(0.002)$ & $(0.004)$ & (0.009) & $(0.003)$ & $(0.003)$ & $(0.003)$ & $(0.003)$ \\
\hline & 0.081 & 0.084 & 0.078 & 0.033 & 0.098 & 0.136 & 0.071 & 0.013 & 0.154 & 0.146 & 0.090 & 0.049 & 0.046 & 0.116 \\
\hline Observations & 49,156 & 23,799 & 25,357 & 13,199 & 35,957 & 7,311 & 41,845 & 25,481 & 23,675 & 4,777 & 26,433 & 17,946 & 24,678 & 24,478 \\
\hline
\end{tabular}

Notes: Each point estimate is from a separate regression. Standard errors in parentheses are clustered at the school level. Control means are in italics below the standard errors. High (low) school poverty is above (below) the median fraction eligible for free or reduced-price lunch.

$* * *=$ significant at $1 \%$ level, $* *=5 \%$ level, $*=10 \%$ level 
$\underline{\text { Table 5. Effects on College Enrollment for Poor Students, by Treatment Type }}$

\begin{tabular}{|c|c|c|c|c|c|c|c|c|c|c|}
\hline \multirow[b]{3}{*}{ Dependent Variable } & \multirow{2}{*}{ Overall } & \multicolumn{4}{|c|}{ Letter Content } & \multicolumn{3}{|c|}{ Letter Timing } & \multicolumn{2}{|c|}{ Website } \\
\hline & & Affordability & $\begin{array}{l}\text { How to } \\
\text { Apply }\end{array}$ & $\begin{array}{l}\text { College } \\
\text { Choice }\end{array}$ & All Three & October & November & December & $\begin{array}{c}\text { Michigan } \\
\text { Site }\end{array}$ & $\begin{array}{c}\text { College } \\
\text { Board Site }\end{array}$ \\
\hline & $(1)$ & (2) & (3) & (4) & (5) & (6) & $(7)$ & (8) & (9) & $(10)$ \\
\hline \multirow[t]{3}{*}{ Enroll in College } & $0.014^{* *}$ & 0.015 & 0.017 & 0.017 & 0.009 & $0.021 * *$ & $0.017^{*}$ & 0.006 & 0.014 & $0.015^{*}$ \\
\hline & $(0.007)$ & $(0.011)$ & $(0.011)$ & $(0.011)$ & $(0.011)$ & $(0.010)$ & $(0.010)$ & $(0.010)$ & $(0.009)$ & (0.009) \\
\hline & 0.764 & 0.764 & 0.764 & 0.764 & 0.764 & 0.764 & 0.764 & 0.764 & 0.764 & 0.764 \\
\hline \multicolumn{11}{|l|}{ By College Level } \\
\hline \multirow[t]{3}{*}{ Four-Year } & $0.017 * *$ & 0.015 & 0.011 & $0.033 * * *$ & 0.010 & $0.022^{*}$ & $0.027 * *$ & 0.003 & $0.018^{*}$ & $0.016^{*}$ \\
\hline & $(0.008)$ & $(0.012)$ & $(0.013)$ & $(0.013)$ & $(0.012)$ & $(0.012)$ & $(0.011)$ & $(0.012)$ & $(0.010)$ & $(0.009)$ \\
\hline & 0.536 & 0.536 & 0.536 & 0.536 & 0.536 & 0.536 & 0.536 & 0.536 & 0.536 & 0.536 \\
\hline \multirow[t]{3}{*}{ Two-Year (only) } & -0.003 & -0.001 & 0.006 & -0.016 & -0.001 & -0.002 & -0.010 & 0.003 & -0.004 & -0.002 \\
\hline & $(0.007)$ & $(0.011)$ & $(0.011)$ & (0.011) & $(0.011)$ & $(0.011)$ & $(0.010)$ & $(0.010)$ & $(0.008)$ & $(0.008)$ \\
\hline & 0.228 & 0.228 & 0.228 & 0.228 & 0.228 & 0.228 & 0.228 & 0.228 & 0.228 & 0.228 \\
\hline Enroll in Selective & $0.005^{*}$ & 0.001 & 0.001 & 0.007 & $0.013^{* *}$ & $0.010 * *$ & $0.008^{*}$ & -0.001 & $0.007^{*}$ & 0.004 \\
\hline \multirow[t]{2}{*}{ Four-Year } & $(0.003)$ & (0.004) & $(0.005)$ & $(0.005)$ & $(0.005)$ & $(0.004)$ & $(0.004)$ & $(0.004)$ & $(0.004)$ & $(0.004)$ \\
\hline & 0.033 & 0.033 & 0.033 & 0.033 & 0.033 & 0.033 & 0.033 & 0.033 & 0.033 & 0.033 \\
\hline Observations & 13,199 & 8,251 & 8,260 & 8,254 & 8,264 & 8,795 & 8,805 & 8,819 & 9,911 & 9,898 \\
\hline
\end{tabular}

Notes: The sample includes only poor students. Each point estimate is from a separate regression. Standard errors in parentheses are clustered at the school level. Control means are in italics below the standard errors. Website refers to the college information website to which students are randomly directed.

Further details on treatment types available in the text.

$* * *=$ significant at $1 \%$ level, $* *=5 \%$ level, $*=10 \%$ level 
Table 6. Effects on College Enrollment and Persistence

\begin{tabular}{|c|c|c|c|}
\hline \multirow[b]{3}{*}{ Dependent Variable } & \multirow[b]{2}{*}{ All } & \multicolumn{2}{|c|}{ By Poverty Status } \\
\hline & & Poor & Non-Poor \\
\hline & (1) & $(2)$ & (3) \\
\hline Enroll in College and Persist to & -0.003 & 0.006 & -0.007 \\
\hline \multirow[t]{2}{*}{ Second Year } & $(0.004)$ & $(0.008)$ & $(0.004)$ \\
\hline & 0.742 & 0.606 & 0.793 \\
\hline Enroll in Four-Year College and & -0.001 & 0.002 & -0.002 \\
\hline \multirow[t]{3}{*}{ Persist to Second Year } & $(0.004)$ & $(0.008)$ & $(0.005)$ \\
\hline & 0.547 & 0.388 & 0.606 \\
\hline & 0.000 & $0.013^{*}$ & -0.004 \\
\hline \multirow[t]{2}{*}{ Immediately Enroll in College } & $(0.003)$ & $(0.007)$ & $(0.004)$ \\
\hline & 0.820 & 0.737 & 0.851 \\
\hline Immediately Enroll in Four-Year & 0.004 & 0.010 & 0.002 \\
\hline \multirow[t]{2}{*}{ College } & $(0.004)$ & $(0.008)$ & $(0.005)$ \\
\hline & 0.613 & 0.486 & 0.660 \\
\hline Immediately Enroll in College & -0.001 & 0.001 & -0.002 \\
\hline \multirow[t]{3}{*}{ And Persist to Third Year } & $(0.004)$ & $(0.008)$ & $(0.005)$ \\
\hline & 0.654 & 0.502 & 0.710 \\
\hline & 0.004 & -0.002 & 0.006 \\
\hline Immediately Enroll in Four-Year & $(0.004)$ & $(0.007)$ & $(0.005)$ \\
\hline College And Persist to Third Year & 0.496 & 0.337 & 0.554 \\
\hline Observations & 49,156 & 13,199 & 35,957 \\
\hline
\end{tabular}

Notes: Each point estimate is from a separate regression. Standard errors in parentheses are clustered at the school level. Control means are in italics below the standard errors.

$* * *=$ significant at $1 \%$ level, $* *=5 \%$ level, $*=10 \%$ level 
Table 7. Exploring Drop-Out Mechanisms

\begin{tabular}{|c|c|c|c|}
\hline \multirow[b]{3}{*}{ Dependent Variable } & \multirow[b]{2}{*}{ All } & \multicolumn{2}{|c|}{ By Poverty Status } \\
\hline & & Poor & Non-Poor \\
\hline & $(1)$ & $(2)$ & (3) \\
\hline \multicolumn{4}{|l|}{ Panel A. Student-College Match } \\
\hline \multirow{3}{*}{$\begin{array}{l}\text { Enroll in Safety College Only } \\
\text { ("Undermatch") }\end{array}$} & -0.001 & -0.005 & 0.001 \\
\hline & $(0.004)$ & $(0.008)$ & $(0.005)$ \\
\hline & 0.392 & 0.390 & 0.392 \\
\hline \multirow[t]{3}{*}{ Enroll in Match College } & -0.000 & $0.018 * *$ & -0.007 \\
\hline & $(0.004)$ & $(0.008)$ & $(0.005)$ \\
\hline & 0.333 & 0.268 & 0.357 \\
\hline Enroll in Reach College & 0.003 & 0.005 & 0.002 \\
\hline \multirow{2}{*}{ ("Overmatch") } & $(0.003)$ & $(0.005)$ & $(0.003)$ \\
\hline & 0.133 & 0.115 & 0.139 \\
\hline \multicolumn{4}{|l|}{ Panel B. Institution Persistence Rate } \\
\hline Enroll in Low-Persistence College & 0.001 & 0.001 & 0.002 \\
\hline \multirow[t]{2}{*}{ Only } & $(0.004)$ & $(0.008)$ & $(0.004)$ \\
\hline & 0.289 & 0.376 & 0.258 \\
\hline \multirow[t]{3}{*}{ Enroll in High-Persistence College } & -0.001 & $0.014^{*}$ & -0.006 \\
\hline & $(0.004)$ & $(0.008)$ & $(0.005)$ \\
\hline & 0.554 & 0.388 & 0.615 \\
\hline \multicolumn{4}{|l|}{ Panel C. Enrollment Intensity } \\
\hline \multirow[t]{3}{*}{ Enroll Part-Time Only } & 0.000 & 0.005 & -0.001 \\
\hline & $(0.003)$ & $(0.007)$ & $(0.004)$ \\
\hline & 0.173 & 0.230 & 0.152 \\
\hline \multirow[t]{3}{*}{ Enroll Full-Time } & 0.000 & 0.009 & -0.003 \\
\hline & $(0.004)$ & $(0.008)$ & $(0.005)$ \\
\hline & 0.670 & 0.534 & 0.720 \\
\hline Observations & 49,156 & 13,199 & 35,957 \\
\hline
\end{tabular}

Notes: Each point estimate is from a separate regression. Standard errors in parentheses are clustered at the school level. Control means are in italics below the standard errors. Safety, match, reach, low-persistence, and high-persistence colleges explained in text $* * *=$ significant at $1 \%$ level, $* *=5 \%$ level, $*=10 \%$ level 
Figure I. Sample Letter (College Affordability Version)

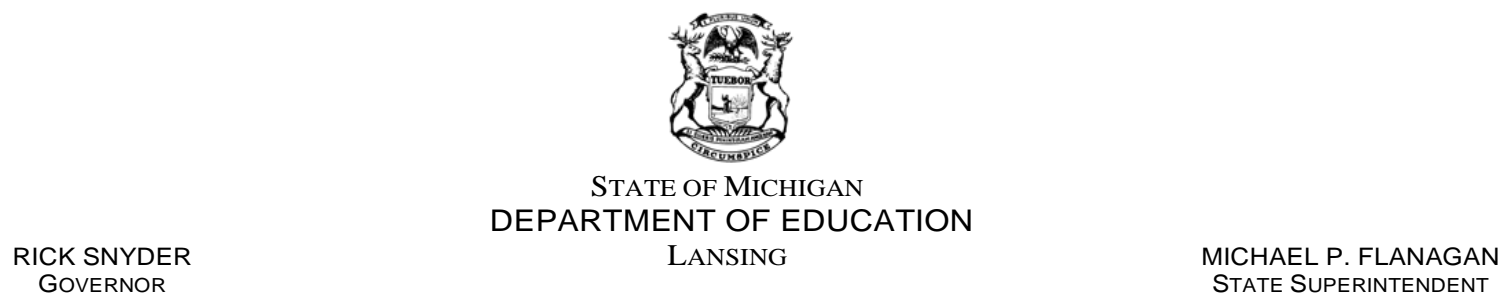

[Student first and last name]

[Student address]

[Student city, state zip]

Dear [Student first name],

Congratulations on your score of [ACT Score] on the ACT, which you took as part of the Michigan Merit Exam in March. Your score suggests that you are ready to enroll and succeed in college. You are receiving this message as a free service from the Michigan Department of Education to ensure that students who are qualified to succeed in college have the information necessary to successfully navigate the application process.

The following link contains information and resources to help you learn how to make college affordable, and more. After navigating to the link, you will need to enter your personal password, provided below.

\section{College Information Website: micollegeinfo.org Your Personal Password: [password]}

By entering your password, you will automatically be entered into a drawing to receive a free iPad Mini!* You can also scan below to navigate to the above link.

If you have any questions about this letter, please call (517)-258-0294 or email hymanj@michigan.gov.

Congratulations again on your ACT score and readiness to succeed in college. I am excited for the benefits that your college attendance and future successes can bring to you and to the State of Michigan. Good luck!

Sincerely,

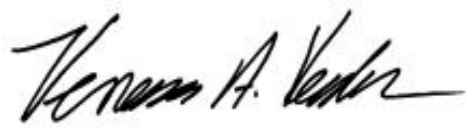

Venessa A. Keesler, Ph.D.

Deputy Superintendent, Education Services

Michigan Department of Education

* NO PURCHASE NECESSARY. Complete rules at micollegeinfo.org/rules.pdf. 
Figure II. Letter Envelope and Gateway Website

(a) Letter Envelope

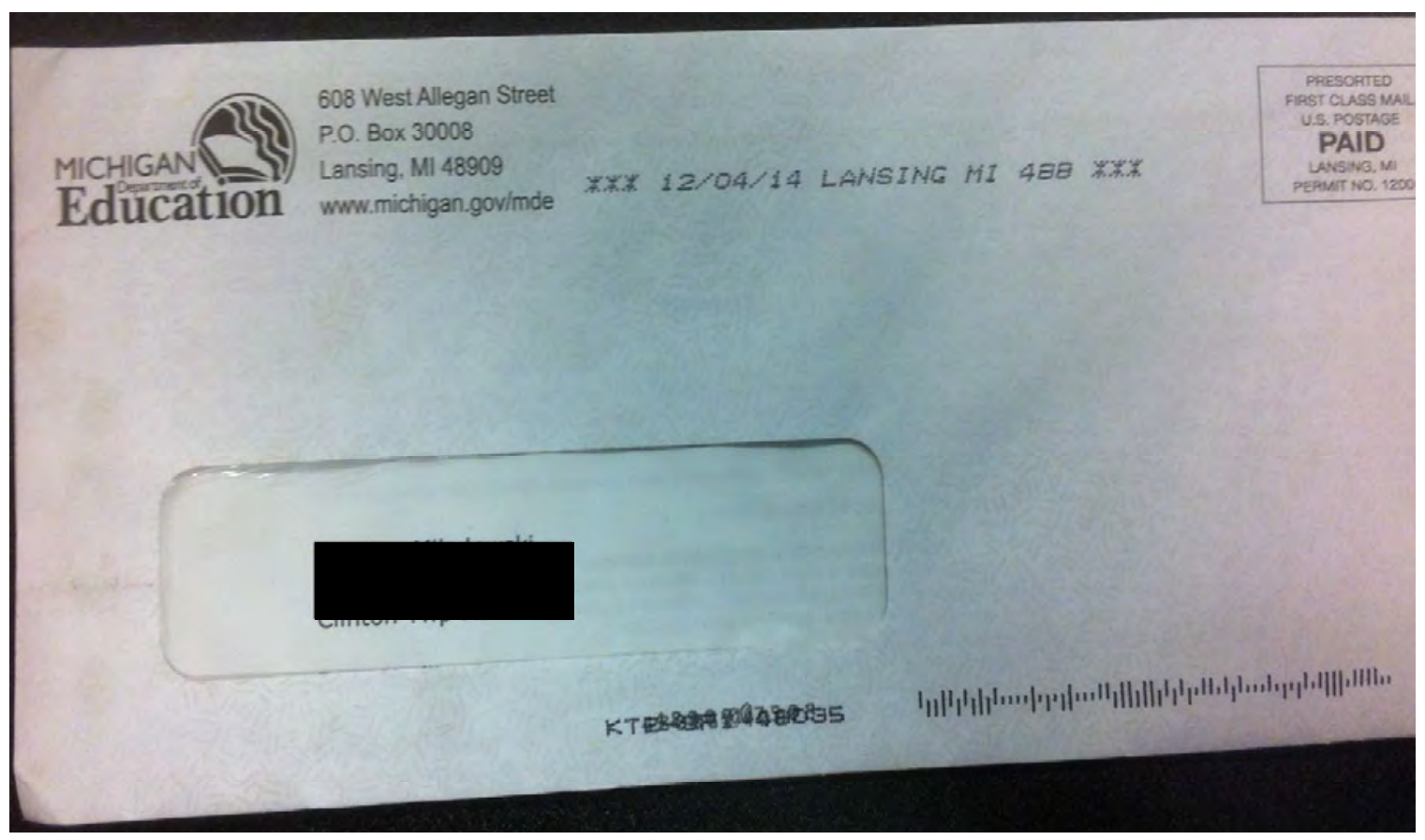

(b) Gateway Website: micollegeinfo.org
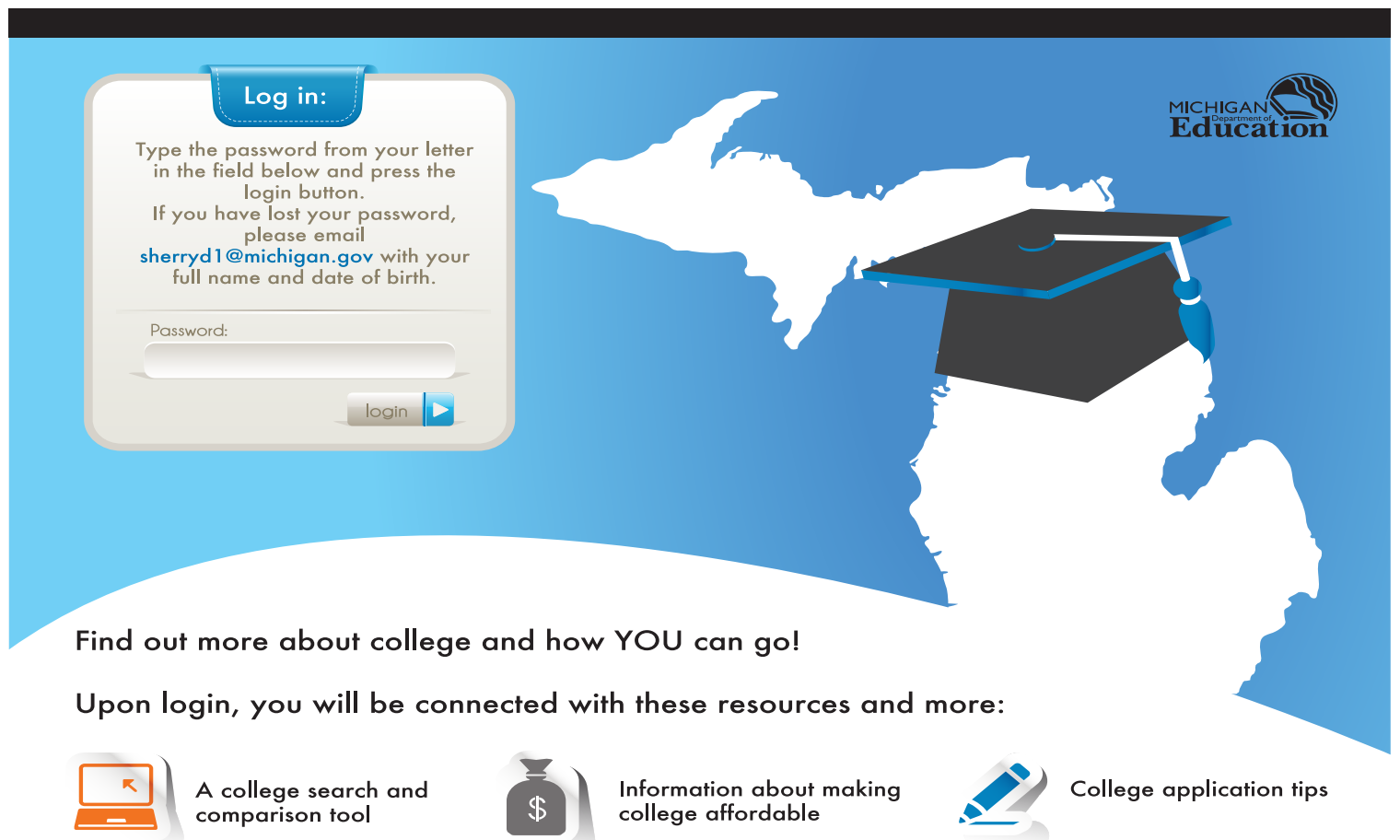

Notes: Figure (a) shows the envelope used to mail the letters. Figure (b) shows the gateway website set up for this project, micollegeinfo.org. 
Figure III. College Information Website One - KnowHow2GOMichigan.org

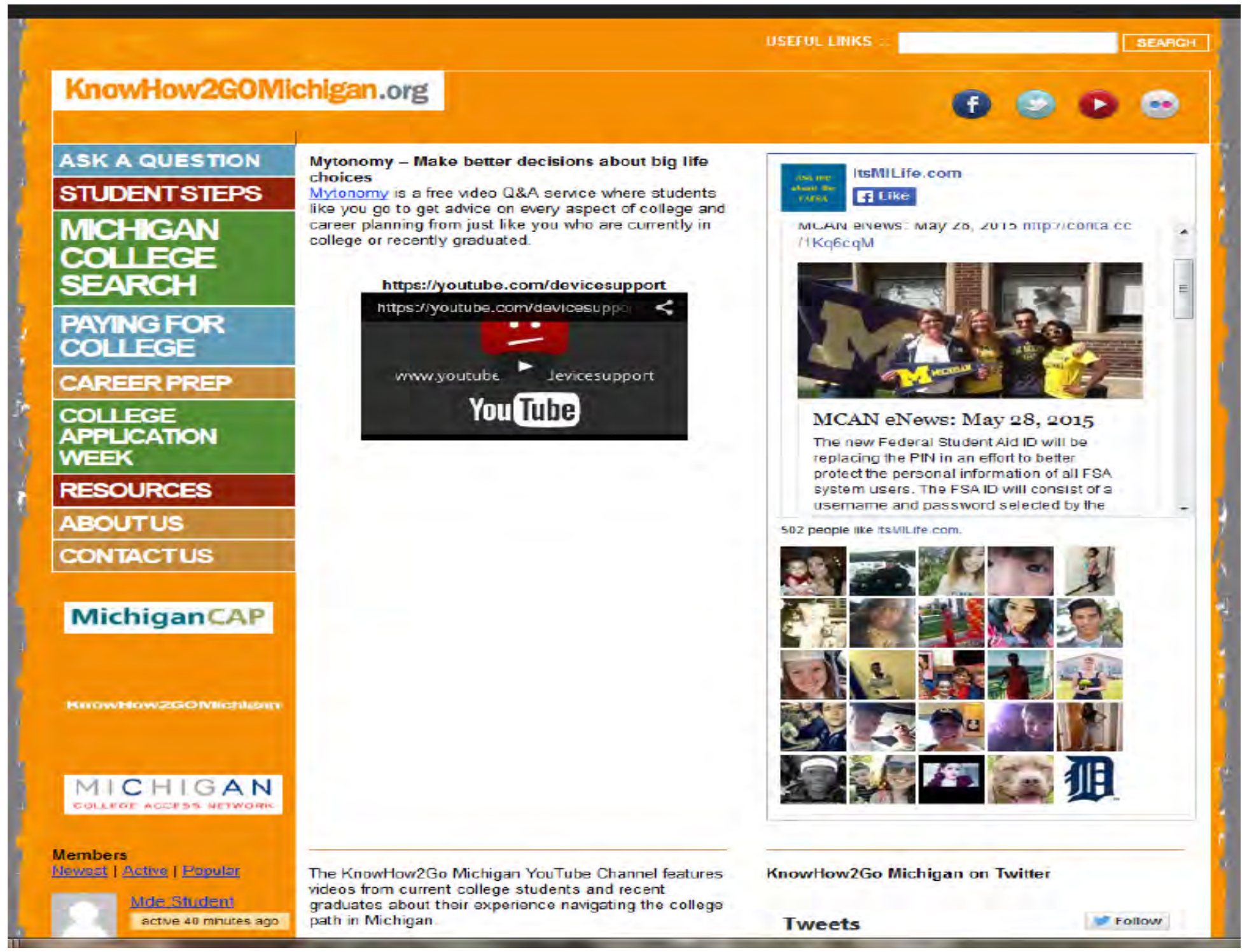


Figure IV. College Information Website Two - College Board BigFuture

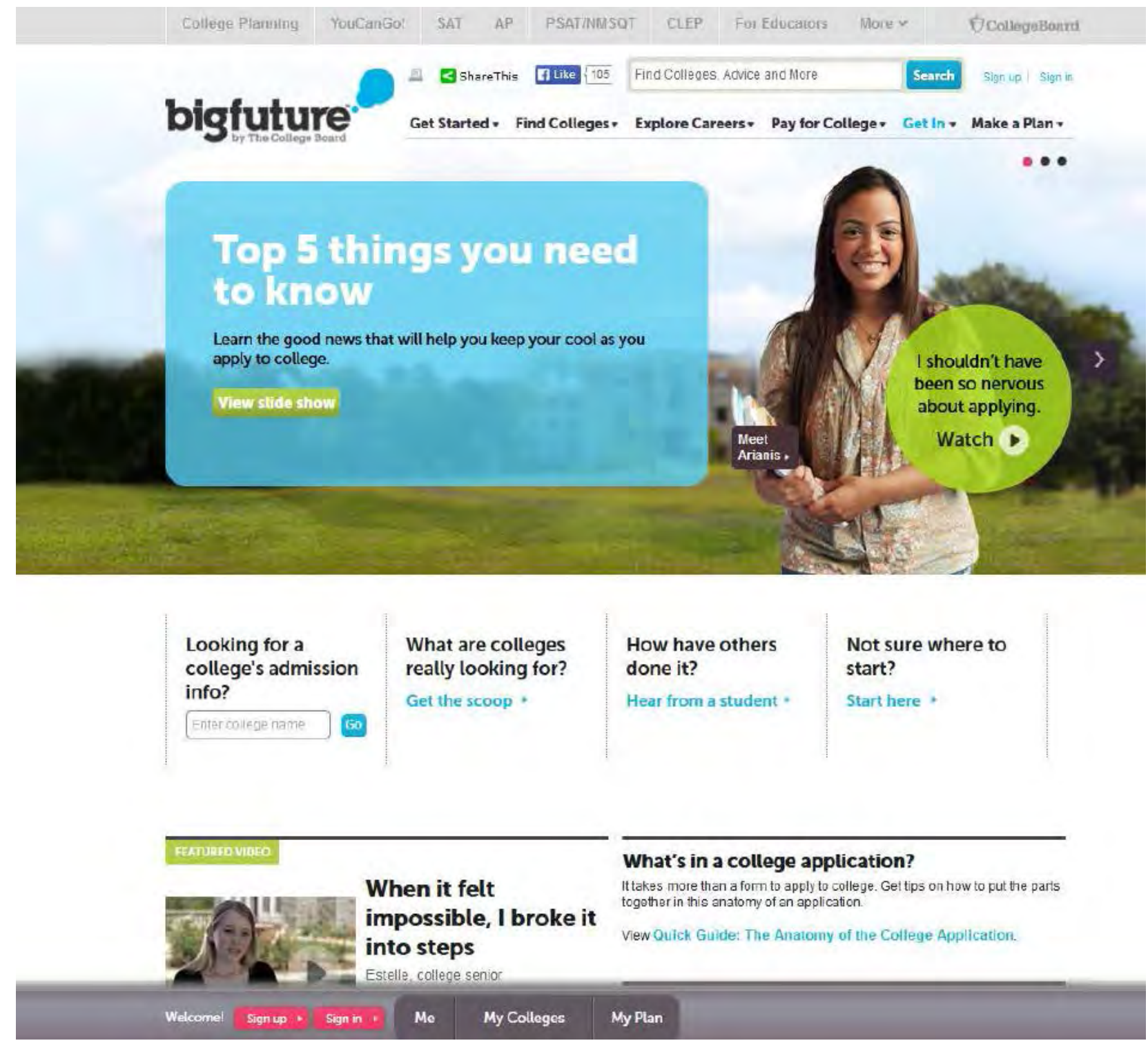


Figure V. Take-Up by Student Poverty Status, Race, and ACT Score

(a) By Student Poverty Status and ACT Score

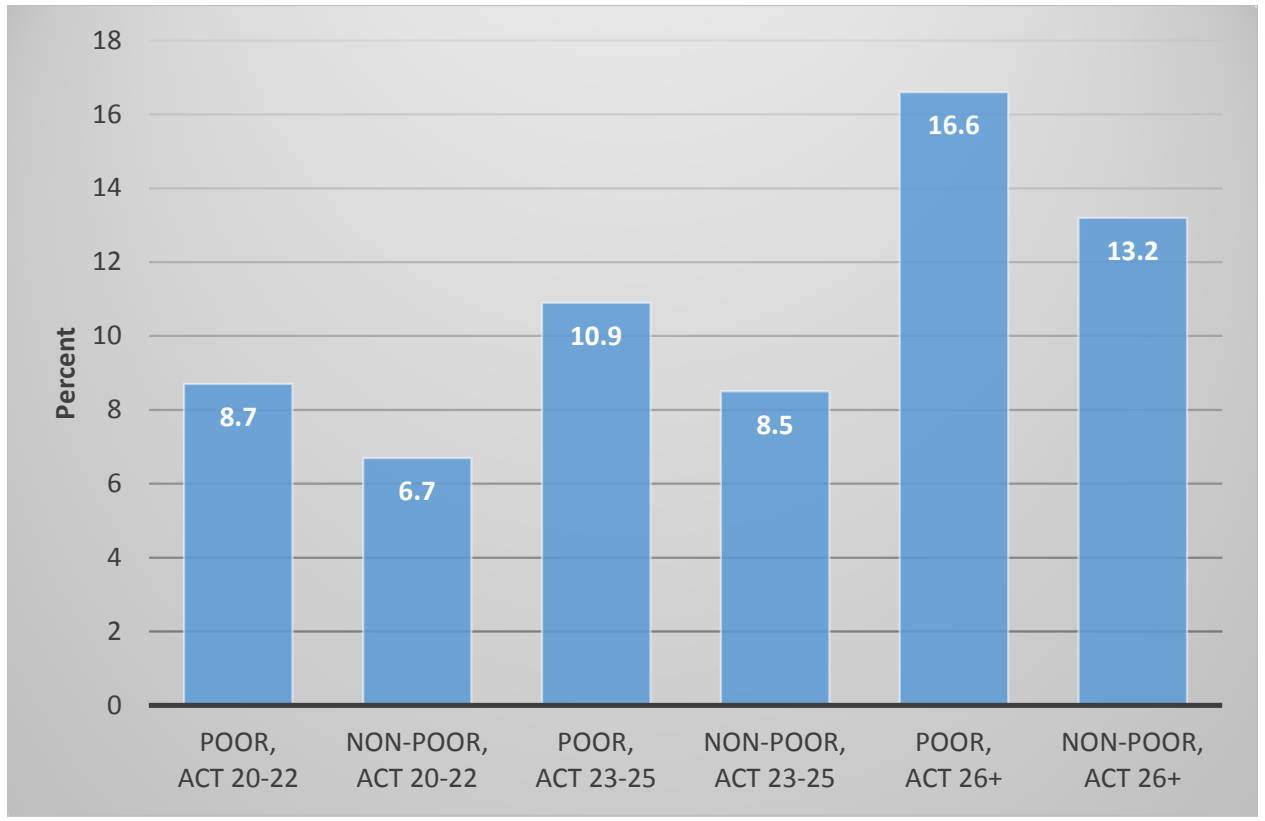

(b) By Student Race and ACT Score

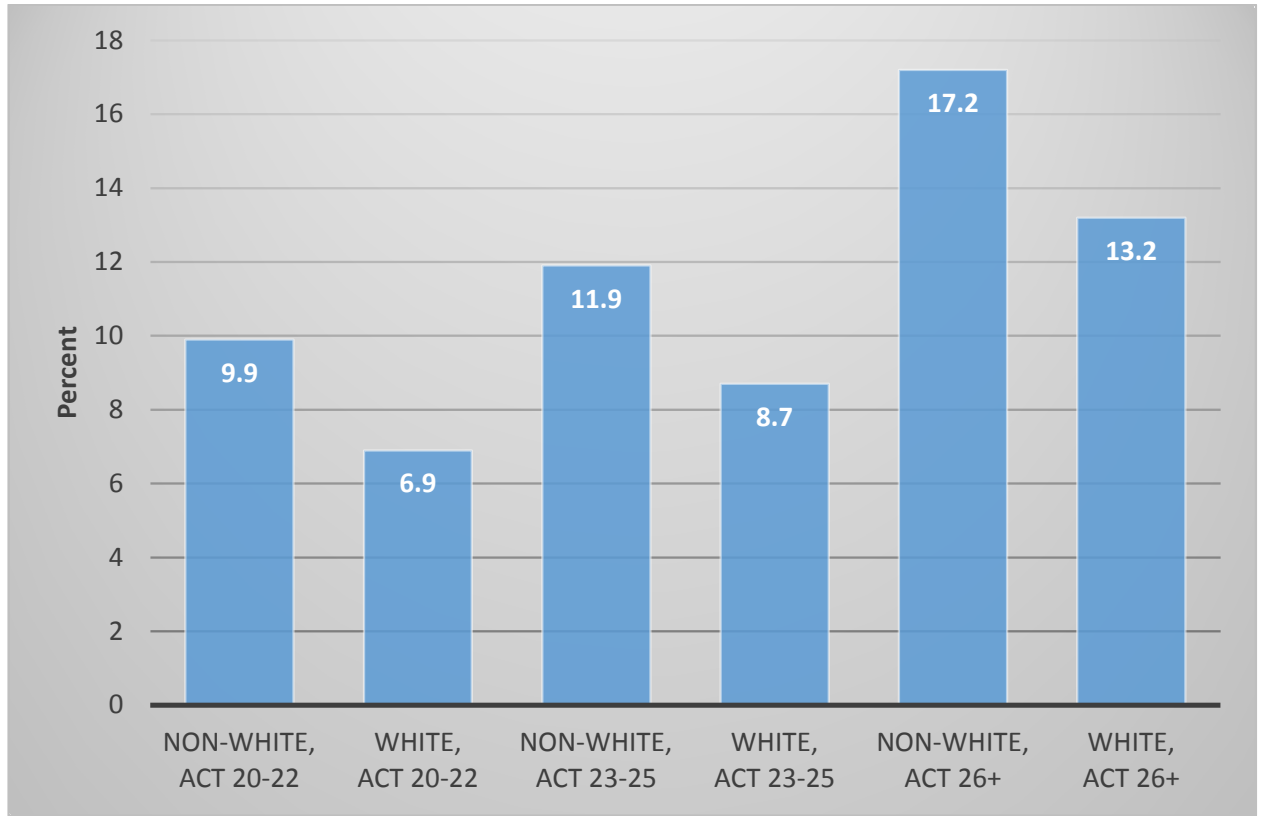

Notes: Figure (a) shows letter take-up rates by student poverty status and ACT score. Figure (b) shows take-up rates by student race and ACT score. Take-up is defined as a student entering his or her password into the gateway website, micollegeinfo.org. The pairwise differences in take-up in figure (a) are all statistically significant at the $95 \%$ level or higher, with the exception of the 8.7 and 8.5 percent take-up among poor, low-scoring students and non-poor, medium-scoring students, respectively. The only pairwise differences in figure (b) that are not significant at the $90 \%$ level or higher are the 9.9 and 11.9 (bars 1 and 3), 9.9 and 8.7 (bars 1 and 4), and 11.9 and 13.2 (bars 3 and 6). 
Figure VI. Take-Up by Student Poverty Status and Letter Content

\section{(a) Poor Students}

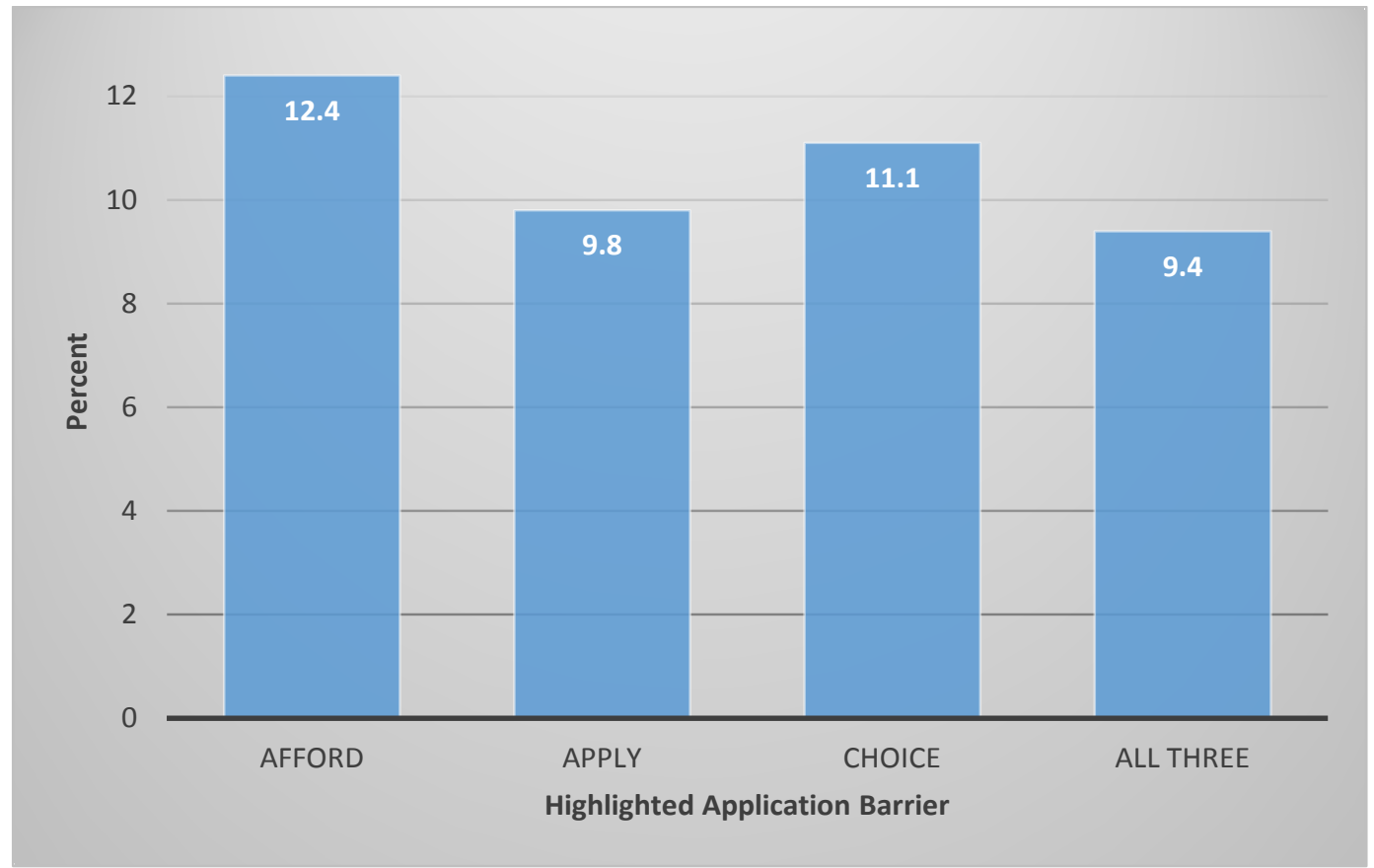

(b) Non-Poor Students

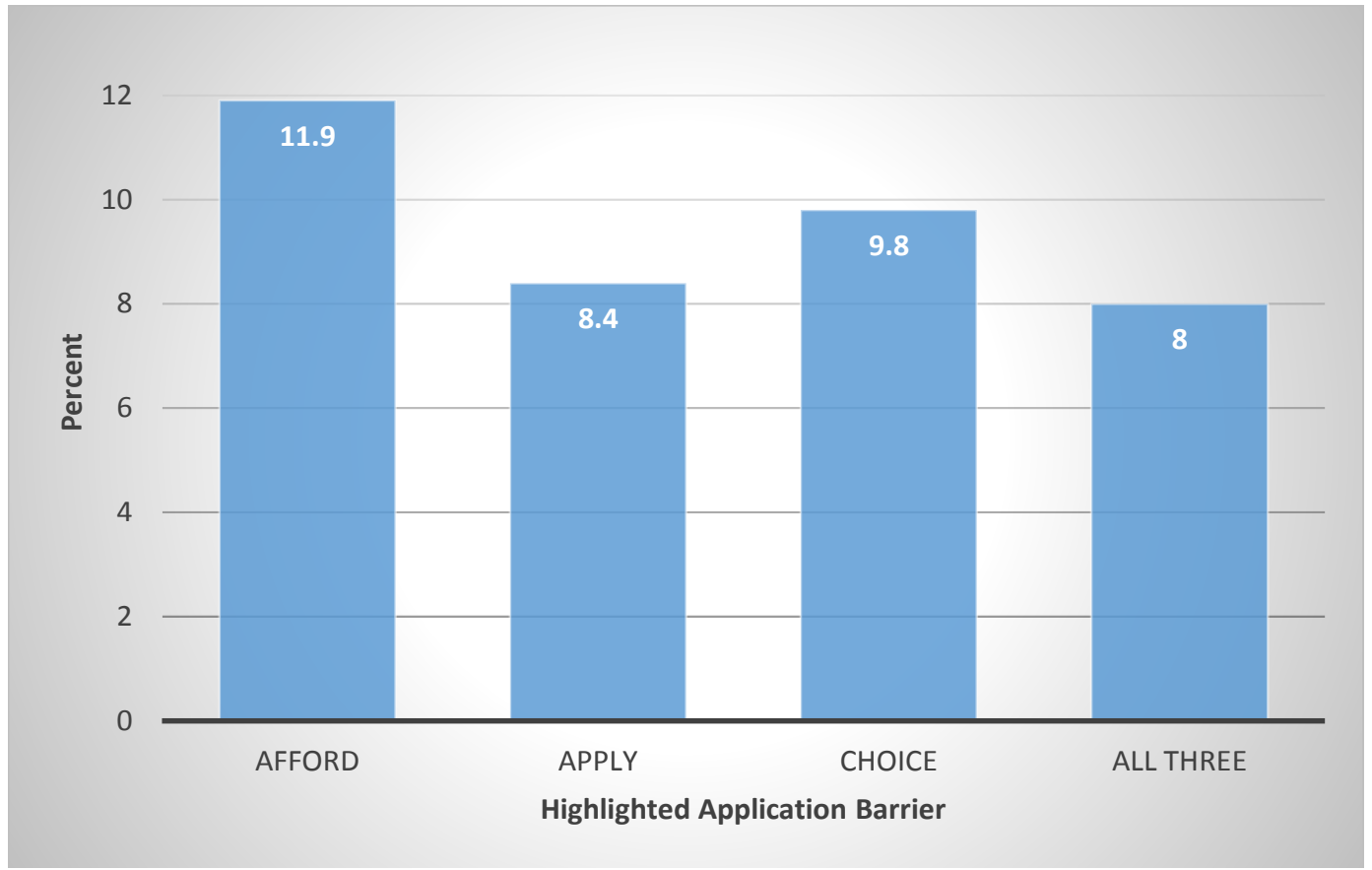

Notes: Figures (a) and (b) show letter take-up rates for poor and non-poor students, respectively, by letter version. Take-up is defined as a student entering his or her password into the gateway website, micollegeinfo.org. The only pairwise differences in figure (a) that are statistically significant at the 95\% level or higher are between "Afford" (12.4) and "Apply" (9.8), and between "Afford" (12.4) and "All Three" (9.4). The only pairwise difference in figure (b) not statistically significant at the $95 \%$ level or higher is the difference between "Apply" (8.4) and "All Three" (8.0). 
Appendix Table 1. Enrollment and Persistence Effects Excluding Controls

\begin{tabular}{lccc} 
& & \multicolumn{2}{c}{ By Poverty Status } \\
\cline { 2 - 4 } Dependent Variable & All & Poor & Non-Poor \\
\cline { 2 - 4 } & $(1)$ & $(2)$ & $(3)$ \\
\hline Enroll in College & 0.001 & $0.015^{* *}$ & -0.004 \\
Enroll in Four-Year College & $(0.003)$ & $(0.007)$ & $(0.004)$ \\
& 0.004 & $0.018^{* *}$ & -0.001 \\
Enroll in Two-Year College (only) & $(0.004)$ & $(0.008)$ & $(0.005)$ \\
Enroll in Selective Four-Year College & -0.003 & -0.003 & -0.003 \\
& $(0.003)$ & $(0.007)$ & $(0.004)$ \\
Enroll in College and Persist to Second Year & 0.003 & $0.006^{*}$ & 0.003 \\
& $(0.003)$ & $(0.003)$ & $(0.003)$ \\
Enroll in Four-Year College and Persist to & -0.002 & 0.007 & -0.006 \\
Second Year & $(0.004)$ & $(0.008)$ & $(0.004)$ \\
Immediately Enroll in College & 0.001 & 0.003 & 0.000 \\
& $(0.005)$ & $(0.008)$ & $(0.005)$ \\
Immediately Enroll in Four-Year College & 0.001 & $0.014^{*}$ & -0.003 \\
& $(0.004)$ & $(0.008)$ & $(0.004)$ \\
Immediately Enroll in College And Persist to & 0.006 & 0.011 & 0.003 \\
Third Year & $(0.005)$ & $(0.009)$ & $(0.005)$ \\
Immediately Enroll in Four-Year College And & 0.006 & 0.002 & -0.001 \\
Persist to Third Year & $(0.005)$ & $(0.008)$ & $(0.006)$ \\
Observations & & -0.001 & 0.008 \\
\hline Notes: Table shows main results from the & & & \\
& 49,156 & 13,199 & 35,957 \\
\hline
\end{tabular}

Notes: Table shows main results from the paper excluding the vector of controls from the estimating equation. Each point estimate is from a separate regression. Standard errors in parentheses are clustered at the school level.

$* * *=$ significant at $1 \%$ level, $* *=5 \%$ level, $*=10 \%$ level 
Appendix Table 2. Enrollment and Persistence Effects Estimating Using Logit

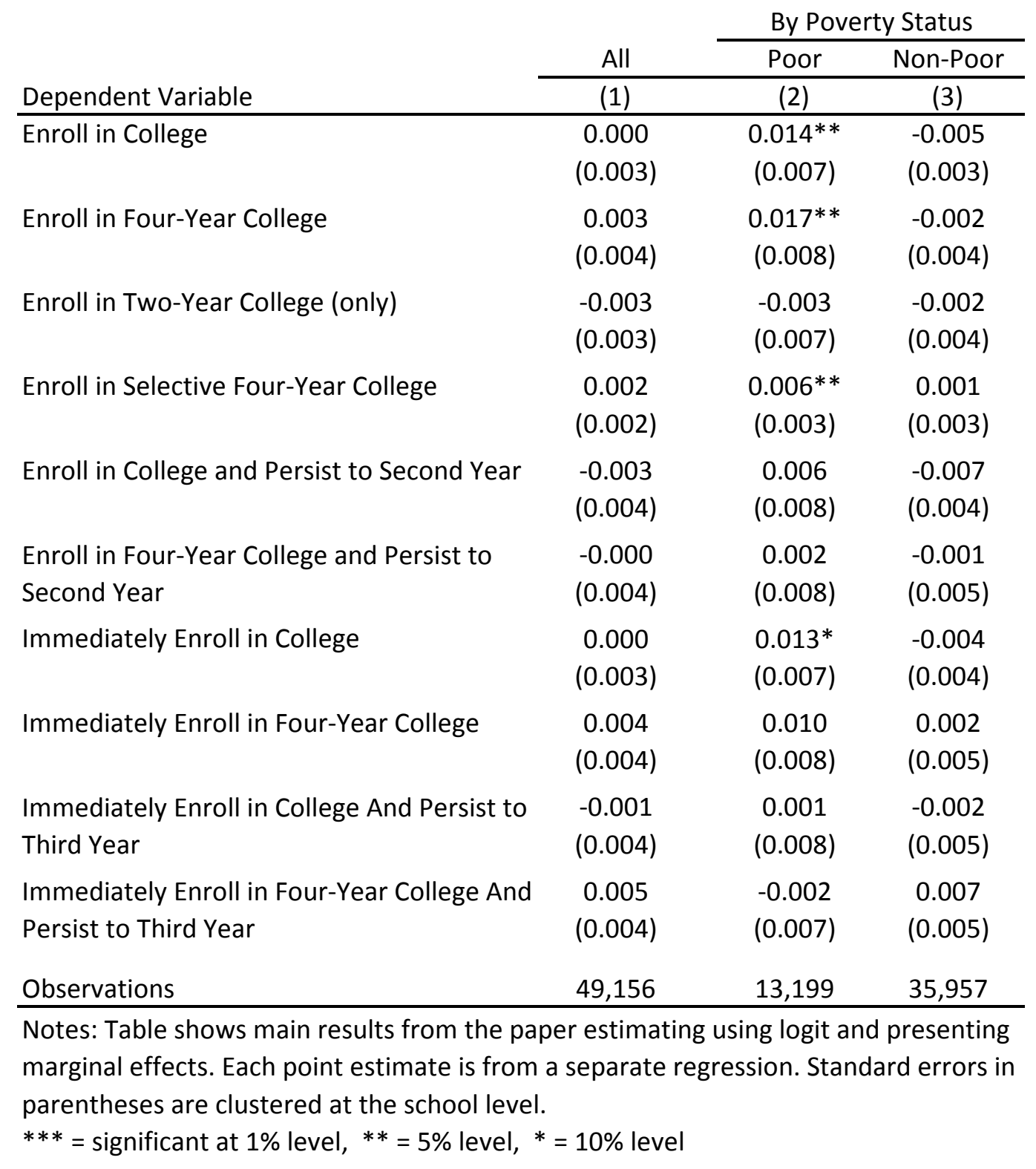




\section{Appendix Figure I. Letter Version Two (How to Apply)}

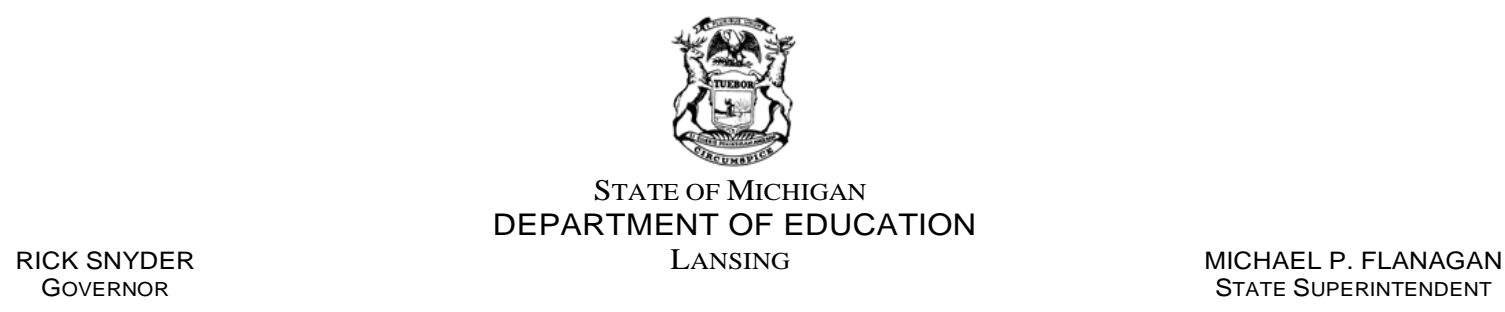

[Student first and last name]

[Student address]

[Student city, state zip]

Dear [Student first name],

Congratulations on your score of [ACT Score] on the ACT, which you took as part of the Michigan Merit Exam in March. Your score suggests that you are ready to enroll and succeed in college. You are receiving this message as a free service from the Michigan Department of Education to ensure that students who are qualified to succeed in college have the information necessary to successfully navigate the application process.

The following link contains information and resources to help you learn how to apply to college, and more. After navigating to the link, you will need to enter your personal password, provided below.

\section{College Information Website: micollegeinfo.org Your Personal Password: [password]}

By entering your password, you will automatically be entered into a drawing to receive a free iPad Mini!* You can also scan below to navigate to the above link.

If you have any questions about this letter, please call (517)-258-0294 or email hymanj@michigan.gov.

Congratulations again on your ACT score and readiness to succeed in college. I am excited for the benefits that your college attendance and future successes can bring to you and to the State of Michigan. Good luck!

Sincerely,

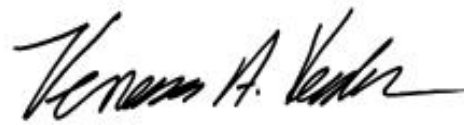

Venessa A. Keesler, Ph.D.

Deputy Superintendent, Education Services

Michigan Department of Education

* NO PURCHASE NECESSARY. Complete rules at micollegeinfo.org/rules.pdf. 


\section{Appendix Figure II. Letter Version Three (College Choice)}

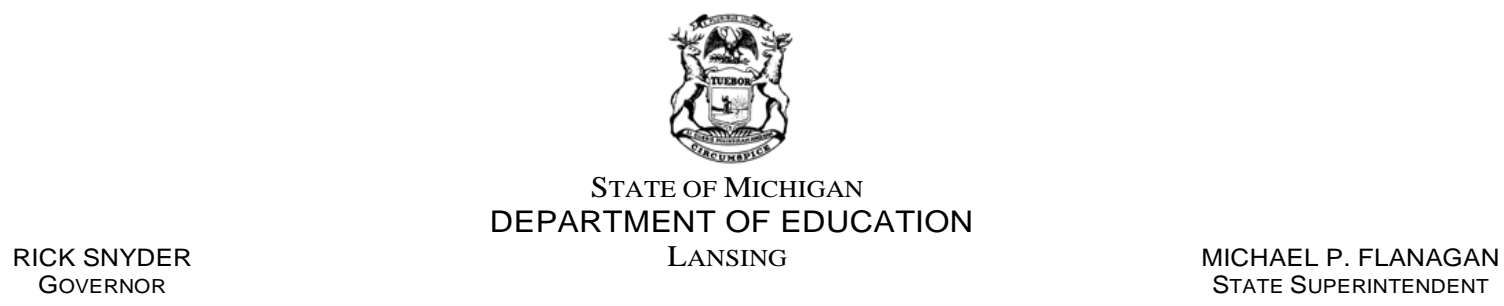

[Student first and last name]

[Student address]

[Student city, state zip]

Dear [Student first name],

Congratulations on your score of [ACT Score] on the ACT, which you took as part of the Michigan Merit Exam in March. Your score suggests that you are ready to enroll and succeed in college. You are receiving this message as a free service from the Michigan Department of Education to ensure that students who are qualified to succeed in college have the information necessary to successfully navigate the application process.

The following link contains information and resources to help you learn which college is right for you, and more. After navigating to the link, you will need to enter your personal password, provided below.

\section{College Information Website: micollegeinfo.org Your Personal Password: [password]}

By entering your password, you will automatically be entered into a drawing to receive a free iPad Mini!* You can also scan below to navigate to the above link.

If you have any questions about this letter, please call (517)-258-0294 or email hymanj@michigan.gov.

Congratulations again on your ACT score and readiness to succeed in college. I am excited for the benefits that your college attendance and future successes can bring to you and to the State of Michigan. Good luck!

Sincerely,

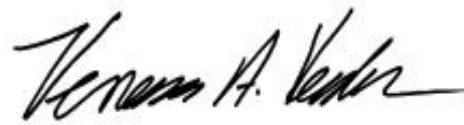

Venessa A. Keesler, Ph.D.

Deputy Superintendent, Education Services

Michigan Department of Education

* NO PURCHASE NECESSARY. Complete rules at micollegeinfo.org/rules.pdf. 


\section{Appendix Figure III. Letter Version Four (Include All Three)}

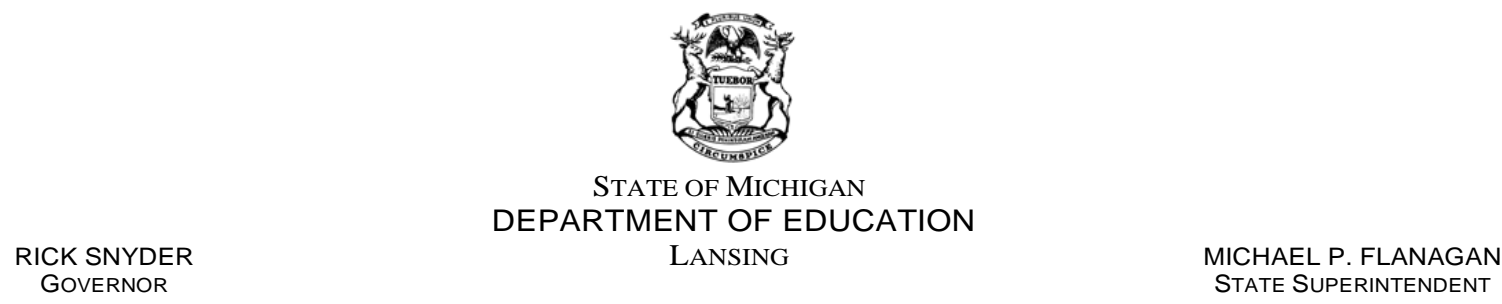

[Student first and last name]

[Student address]

[Student city, state zip]

Dear [Student first name],

Congratulations on your score of [ACT Score] on the ACT, which you took as part of the Michigan Merit Exam in March. Your score suggests that you are ready to enroll and succeed in college. You are receiving this message as a free service from the Michigan Department of Education to ensure that students who are qualified to succeed in college have the information necessary to successfully navigate the application process.

The following link contains information and resources to help you learn: a) how to apply to college, b) how to make college affordable, and c) which college is right for you. After navigating to the link, you will need to enter your personal password, provided below.

\section{College Information Website: micollegeinfo.org Your Personal Password: [password]}

By entering your password, you will automatically be entered into a drawing to receive a free iPad Mini!* You can also scan below to navigate to the above link.

If you have any questions about this letter, please call (517)-258-0294 or email hymanj@michigan.gov.

Congratulations again on your ACT score and readiness to succeed in college. I am excited for the benefits that your college attendance and future successes can bring to you and to the State of Michigan. Good luck!

Sincerely,

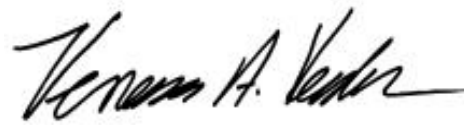

Venessa A. Keesler, Ph.D.

Deputy Superintendent, Education Services

Michigan Department of Education

*NO PURCHASE NECESSARY. Complete rules at micollegeinfo.org/rules.pdf. 
Appendix Figure IV. Take-Up by Student ACT Score, Poverty, and Urbanicity

(a) By Student Poverty and High School Urbanicity

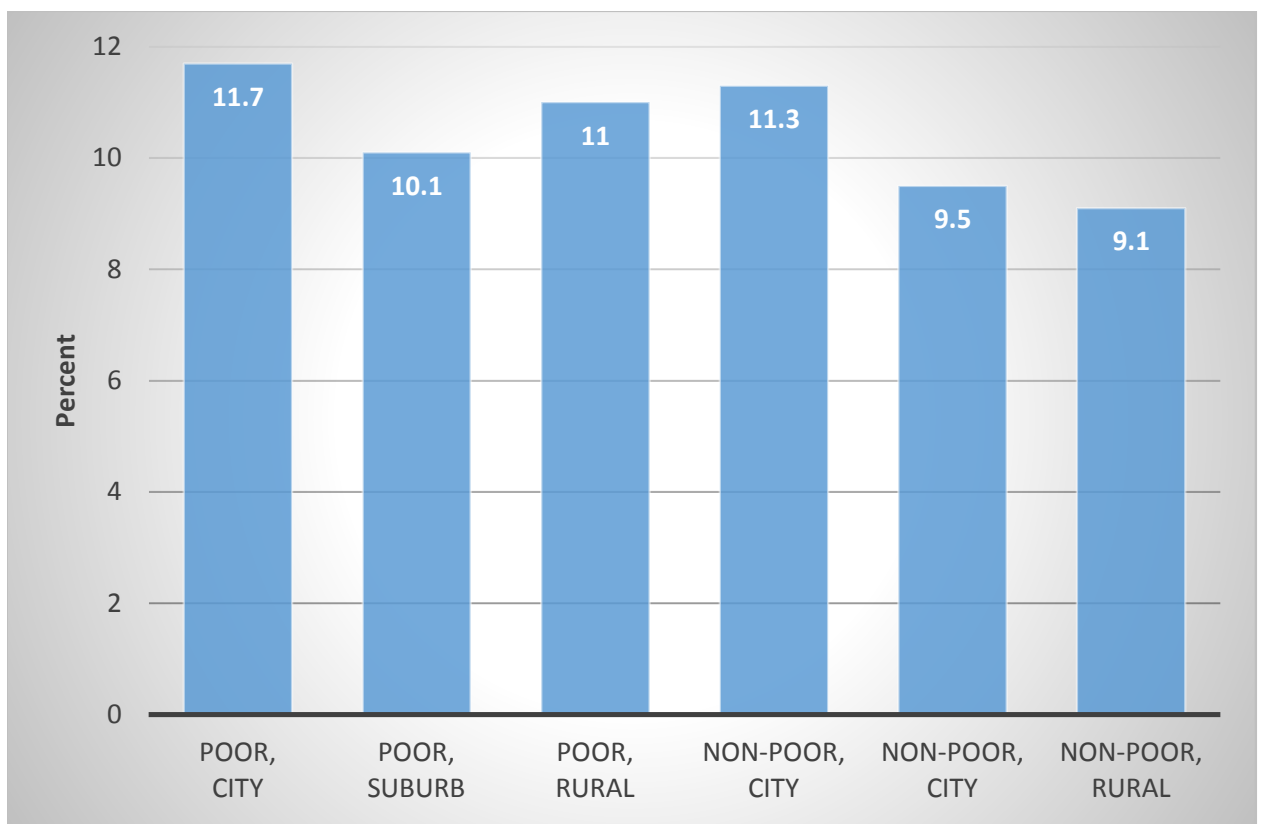

(b) By Student ACT Score

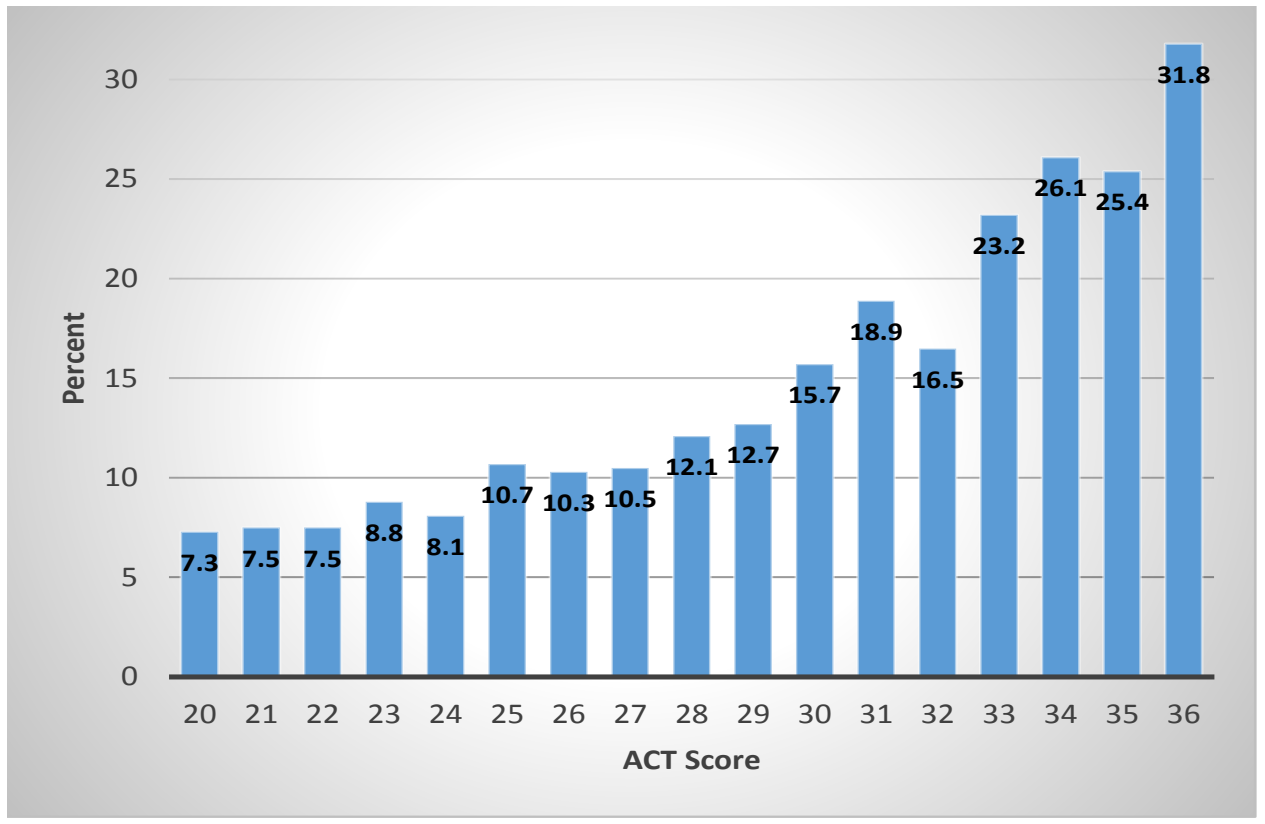

Notes: Figure (a) shows letter take-up rates by student poverty status and high school urbanicity. Figure (b) shows rates by student ACT score. Take-up is defined as a student entering his or her password into the gateway website, micollegeinfo.org. 